\title{
Botswana: 2003 Article IV Consultation-Staff Report; Staff Supplement; Public Information Notice on the Executive Board Discussion; and Statement by the Executive Director for Botswana
}

Under Article IV of the IMF's Articles of Agreement, the IMF holds bilateral discussions with members, usually every year. In the context of the 2003 Article IV consultation with Botswana, the following documents have been released and are included in this package:

- $\quad$ the staff report for the 2003 Article IV consultation, prepared by a staff team of the IMF, following discussions that ended on December 3, 2003, with the officials of Botswana on economic developments and policies. Based on information available at the time of these discussions, the staff report was completed on March 9, 2004. The views expressed in the staff report are those of the staff team and do not necessarily reflect the views of the Executive Board of the IMF.

- $\quad$ a staff supplement of March 23, 2004 updating information on recent developments.

- $\quad$ a Public Information Notice (PIN) summarizing the views of the Executive Board as expressed during its March 24, 2004 discussion of the staff report that concluded the Article IV consultation.

- $\quad$ a statement by the Executive Director for Botswana.

The document listed below have been or will be separately released.

Selected Issues Paper and Statistical Appendix

The policy of publication of staff reports and other documents allows for the deletion of market-sensitive information.

To assist the IMF in evaluating the publication policy, reader comments are invited and may be sent by e-mail to publicationpolicy@imf.org.

Copies of this report are available to the public from

International Monetary Fund • Publication Services

$70019^{\text {th }}$ Street, N.W. • Washington, D.C. 20431

Telephone: (202) 623-7430 • Telefax: (202) 623-7201

E-mail: publications@imf.org・Internet: http://www.imf.org

Price: $\$ 15.00$ a copy

\section{International Monetary Fund}

Washington, D.C. 



\title{
INTERNATIONAL MONETARY FUND
}

\author{
BOTSWANA
}

\section{Staff Report for the 2003 Article IV Consultation}

Prepared by Staff Representatives for the 2003 Consultation with Botswana

Approved by Juan Carlos Di Tata and Anthony Boote

March 9, 2004

- The 2003 Article IV consultation discussions were held in Gaborone during November 19December 3, 2003. The mission chief met with President Festus Mogae, and the team met with the Minister of Finance and Development Planning (MFDP), Hon. Baledzi Gaolathe, the Bank of Botswana (BOB) Governor, Mrs. Linah Mohohlo, the Permanent Secretary of MFDP, Mr. Serwalo Tumelo, other senior government officials, and representatives of the private sector and civil society.

- The mission team comprised Messrs. Kibuka (Head) and Akatu, and Ms. Kim and Ms. Masha (all AFR), Mr. Zaidi (FIN), and Ms. Kabia (Admin. Assistant, AFR). Mr. Steytler, Advisor to Botswana's Executive Director, participated in the policy discussions.

- At the conclusion of the last Article IV consultation on October 9, 2002, Executive Directors urged the authorities to use the forthcoming Ninth National Development Plan as a tool for addressing the budgetary impact of HIV/AIDS in a comprehensive manner, and for making the difficult choices concerning government resources and spending in a medium-term policy framework.

- Botswana's core economic database is largely adequate for surveillance, although the quality and timeliness of national accounts and key trade data need to be improved. A ROSC mission in 2001 advised the authorities to align different reporting periods for the major sectors and to enhance coordination among the data-compiling agencies. Botswana is a participant in the Fund's General Data Dissemination System (GDDS). Botswana's relations with the Fund, including technical assistance, are summarized in Appendix I, and its relations with the World Bank Group in Appendix II. Statistical issues are described in Appendix III. Social and demographic indicators are provided in Appendix IV.

- Botswana accepted the obligations of Article VIII, Sections 2 (a), 3, and 4 on November 17, 1995. It maintains an exchange system that is free of restrictions on the making of payments and transfers for current international transactions, except for a multiple currency practice that is expected to expire in 2006, as discussed in paragraph 33 . Botswana also maintains a liberal regime for capital account transactions.

- Botswana will be holding elections for the parliament (which will then elect the president shortly thereafter) likely in the fourth quarter of 2004. President Mogae is seeking a second term in office. 


\section{Contents}

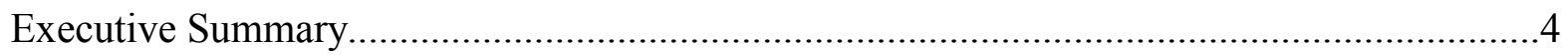

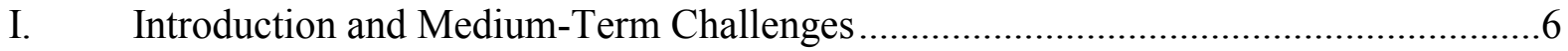

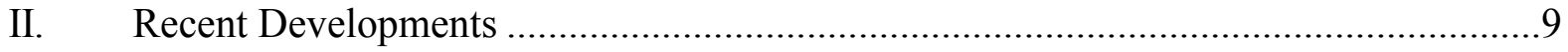

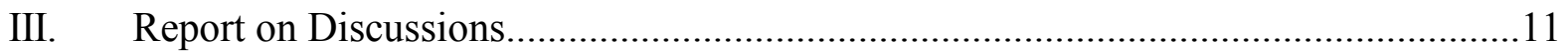

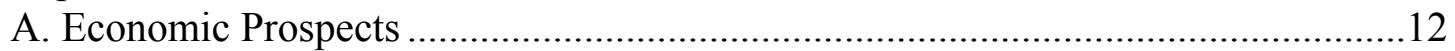

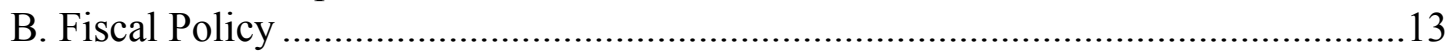

C. Monetary and Exchange Rate Policies ................................................................ 15

D. Medium-Term External Outlook ...................................................................... 18

E. Structural Reforms and Statistical Issues ........................................................... 19

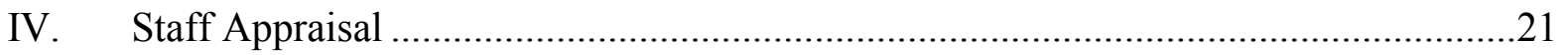

Boxes

1. Recent Developments in HIV/AIDS in Botswana ................................................

2. Botswana's Ninth National Development Plan (NDP 9), 2003/04-2008/09 ...............8

Figures

1. Botswana and Selected Countries: Per Capita GDP, 1980-2003 _...........................24

2. Main Economic Indicators, 1990-2003 .................................................................25

3. Selected Fiscal Indicators, 1996/97-2003/04 ….....................................................26

4. $\quad$ Selected Exchange Rate Indicators, January 1995-December 2003 ........................27

Tables

1. Selected Economic and Financial Indicators, 1999-2004 ...................................28

2. Sectoral GDP and Savings-Investment Balances, 1996/97-2003/04 ........................29

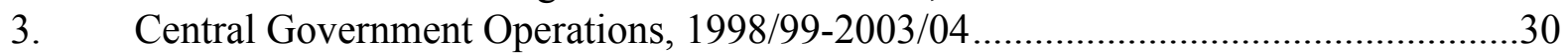

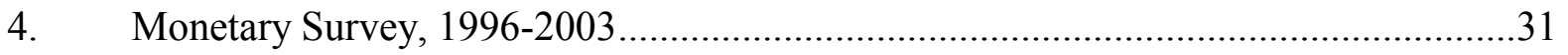

5. Assets and Liabilities of the Bank of Botswana, 1996-2003 …...............................32

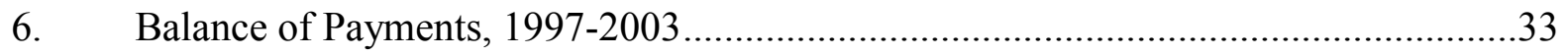

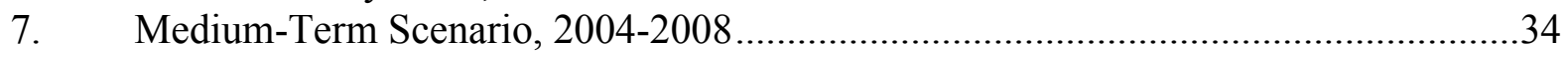

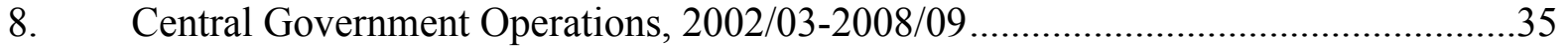

9. Balance of Payments Medium-Term Scenario, 2001-2008 …...................................36

10. Public Sector Debt Sustainability Framework, 1998-2008 ........................................37

11. External Debt Sustainability Framework, 1998-2008............................................38 
Appendices

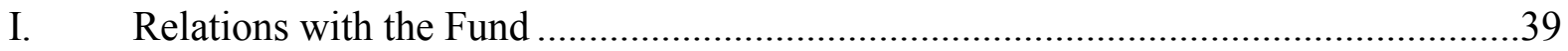

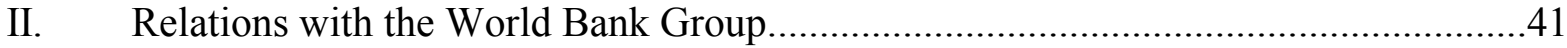

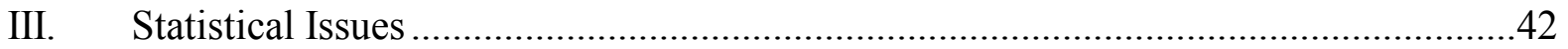

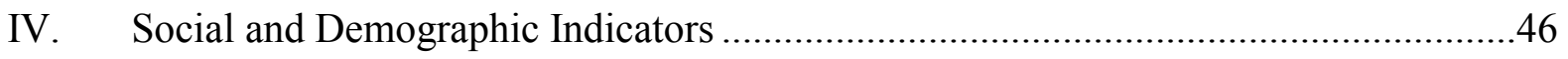




\section{Executive Summary}

- Following several years of rapid economic growth with stable macroeconomic policies, Botswana faces difficult challenges in the years ahead, as diamond production is near full capacity and an HIV/AIDS epidemic threatens to undermine past economic gains.

- During 2003/04, ${ }^{1}$ efficiency gains in diamond production are expected to contribute to real GDP growth of 5.4 percent. At the same time, inflation declined to 6.4 percent during 2003 (11.2 percent in 2002) in response to the central bank's prudent monetary policy. The overall fiscal deficit is expected to decline to below 1 percent of GDP in 2003/04, while the external current account would remain in surplus for 2003. The international reserves position remains strong, with a cover estimated at about 25 months of imports.

- In 2003, Botswana launched the Ninth National Development Plan for 2003/042008/09 (NDP 9), which outlines a strategy to diversify the economy and to combat HIV/AIDS, including the free provision of antiretroviral drugs. In addition, the country prepared a National Strategic Framework (NSF) for HIV/AIDS (2003-09), and a National Strategy for Poverty Reduction (NSPR), neither of which have yet been fully integrated into the NDP 9 macroeconomic framework.

- Medium-term growth is projected to slow because of the plateauing of diamond production, the impact of HIV/AIDS, and accelerating social expenditure. In the absence of policy adjustments, the more moderate rates of growth are likely to lead to a significant worsening of fiscal and external balances, compared with the last several years.

- The authorities concurred on the need to strengthen tax administration, especially VAT compliance, via the introduction of an autonomous revenue authority. They are also scrutinizing expenditure in line with the country's priorities and are introducing user charges (e.g., school fees) to recover costs while protecting the poor via safety nets. The authorities have also requested Fund technical assistance to improve expenditure tracking for the priority sectors.

- The authorities intend to maintain the present exchange system based on a peg of the pula to a basket of currencies. The pula was devalued by 7.5 percent against

\footnotetext{
${ }^{1}$ The national accounts data cover the period July-June and the fiscal data cover AprilMarch, while the balance of payments and monetary data are on the basis of the calendar year.
} 
the basket in February 2004 to partly reverse its real effective appreciation in recent years; the current level of the exchange rate appears to be broadly appropriate. The authorities are implementing a number of structural reforms and are participating in regional efforts to improve access to export markets; these steps will help to maintain external competitiveness and promote economic diversification. In this context, the staff stressed the need to maintain a prudent fiscal policy to support the exchange rate peg.

- Financial sector reforms, including a partial privatization of the civil service pension scheme, are an important part of the economic strategy. The increased risk associated with these reforms should be addressed through enhanced supervision of the sector. The authorities are making efforts to strengthen monetary management. The staff stressed the need to enhance the coordination of fiscal and monetary policies in order to reduce pressure on interest rates and encourage private sector activity.

- The authorities agreed on the importance of continuing with efforts to improve the coverage and timeliness of data compilation, including through the establishment of an autonomous Central Statistics Office (CSO).

\begin{tabular}{|c|c|c|c|c|c|c|}
\hline & 1998 & 1999 & 2000 & 2001 & 2002 & 2003 \\
\hline & & & & & Est. & Est. \\
\hline & \multicolumn{6}{|c|}{ (Annual percentage change) } \\
\hline GDP at constant 1993/94 market price 1 / & 4.1 & 6.6 & 8.4 & 2.3 & 5.5 & 5.4 \\
\hline Consumer prices (average) & 6.5 & 7.8 & 8.5 & 6.6 & 8.0 & 9.3 \\
\hline Consumer prices (e-o-p) & 6.4 & 8.4 & 8.5 & 5.7 & 11.2 & 7.5 \\
\hline \multirow[t]{2}{*}{ Broad Money (M3) } & 21.0 & 27.8 & 22.3 & 16.4 & 15.1 & 18.5 \\
\hline & \multicolumn{6}{|c|}{ (In percent of GDP) } \\
\hline Budget balance (including grants) $2 /$ & -6.0 & 6.4 & 9.3 & -3.1 & -4.1 & -0.7 \\
\hline External current account balance (deficit -) 3/ & 4.1 & 12.3 & 10.4 & 11.5 & 11.6 & 11.0 \\
\hline Gross Reserves (months of imports) & 28.2 & 31.1 & 32.5 & 33.0 & 30.6 & 25.2 \\
\hline Nominal GDP (in billions of pula) $1 /$ & 21.5 & 24.9 & 28.7 & 32.0 & 34.9 & 38.2 \\
\hline
\end{tabular}

Sources: Botswana authorities and Fund staff estimates and projections.

1/ July-June.

2/ April-March.

3/ Calendar year. 


\section{INTRODUCTION AND MEDIUM-TERM CHALLENGES}

1. Over the past 35 years, Botswana has been among the best performing economies in Africa (Figure 1). It has evolved from one of the poorest countries in the world to a middle-income country with the highest sovereign credit rating in the region. Sound economic policies, especially in managing its large diamond resources, and a commitment to democracy have contributed to this success. However, Botswana now faces the challenges of a plateauing in diamond production and one of the highest HIV/AIDS infection rates in the world (Box 1). These factors threaten the economic success that has been achieved to date.

2. Faced with these problems, Botswana needs to develop appropriate social safety nets and implement policies aimed at sustaining and broadening economic growth, which is expected to decelerate relative to the high rates experienced over the past 35 years. In this regard, the Ninth National Development Plan (NDP 9; Box 2) is a timely elaboration on the authorities' medium-term economic strategy. However, the NDP 9 incorporates only some of the programs to address the HIV/AIDS epidemic. Moreover, the costing and coverage of these programs have not been consolidated into a line item in the budget, which precludes a full analysis of their fiscal implications.

3. During 2003, the authorities prepared a comprehensive National Strategic Framework (NSF) for HIV/AIDS that consolidates all the programs related to the epidemic, as well as available donor support, and is considered to be among the best in Africa. In a similar vein, the government launched a National Strategy for Poverty Reduction (NSPR) that discusses the efforts being made in this area and complements the NSF. Looking ahead, an important challenge is to integrate these various strategies into a common mediumterm budgetary expenditure framework. This step is critical to formulating an appropriate expenditure policy response and mobilizing domestic resources to achieve the NDP 9 goal of a balanced budget.

4. Reforms in the financial sector form an integral part of the economic diversification strategy and pose a major challenge to the authorities. The recent launching of an offshore center and the government's transfer of accumulated pension benefits amounting to $\mathrm{P} 10.5$ billion ( 27 percent of GDP) to private pension fund managers (as part of the civil service pension reform) entail risks that require enhanced financial supervision. These reforms, together with the recent introduction of government bonds, also have implications for the conduct of monetary policy. Moreover, with the authorities' increased interest in refining the monetary policy framework, there is a need to strengthen the Central Statistics Office (CSO) in order to improve the timeliness and accuracy of macroeconomic data.

5. A successful transformation of the economy hinges on maintaining macroeconomic stability, while improving the implementation and coordination of structural reforms to broaden and sustain growth. For many years, the authorities have 


\section{Box 1. Recent Developments in HIV/AIDS in Botswana}

Botswana's relatively promising ranking on development indicators has been adversely affected by the HIV/AIDS epidemic. According to a 2001 national survey, the HIV/AIDS infection rate for adults is estimated at about 35.4 percent. The overall prevalence rate has more than doubled since 1992, and an estimated 138,000 Batswana had died of AIDS by 2002, with 69,000 children orphaned by the epidemic. The effects of such high prevalence rates on human development have been remarkable. According to the 2001 census, life expectancy had fallen from 65 years to 56 years, and infant mortality rate had risen from 48 per 1000 live births in 1992 to 55.2 in 2001 . Similarly, the population is projected to decline to 1.3 million in 2015 , compared with a no-AIDS scenario of 2.5 million.

Table 1. HIV/AIDS Infection Rate (In Percent)

\begin{tabular}{lcrrr}
\hline & $\begin{array}{c}\text { Adults } \\
\text { (Aged }\end{array}$ & \multicolumn{3}{c}{ Women in Antenatal } \\
& $15-49)$ & \multicolumn{3}{c}{ Care Clinics } \\
\hline & 2001 & 1992 & 2002 & \\
Swaziland & 33.4 & 4.0 & 38.6 & \\
South Africa & 20.1 & 2.5 & 22.4 & $(2000)$ \\
Botswana & 35.4 & 13.8 & 36.3 & $(2001)$ \\
Zimbabwe & 35.7 & & 35.0 & $(2000)$ \\
Lesotho & 31.0 & & 42.2 & \\
\hline
\end{tabular}

Sources: Botswana authorities; World Bank, and World Development Indicators.
Table 2. Social Indicators in Botswana

\begin{tabular}{lrr}
\hline & 1992 & 2001 \\
\hline Population growth rate, in percent & 2.8 & 0.8 \\
Infected adults & $78,300.0$ & $313,800.0$ \\
$\quad$ (Percent of adults) & 11.0 & 35.4 \\
Dependency ratio & 1.0 & 0.9 \\
Life expectancy & 65.0 & 56.0 \\
AIDS mortality (percent of deaths) & 10.0 & 23.0 \\
Infant mortality rate & & \\
$\quad$ (per 1,000 life births & 48.0 & 55.2 \\
\hline Source: Botswana 2002 Second-Generation HIV/AIDS \\
$\quad$ Surveillance.
\end{tabular}

The economic impact of HIV/AIDS in Botswana in a static, no-treatment has been well researched. In a model by McFarlane and Sgherri $(2001)^{1}$, nonmining GDP growth is projected at 1.38 percent in 2010, compared with 5.2 percent in the absence of the epidemic. In another study by Haacker $(2002)^{2}$, output per capita in Botswana was found to decline by 10.2 percent in the medium term as a result of the negative consequences of HIV/AIDS.

The HIV/AIDS epidemic poses a serious challenge to the achievement of the government's objectives of poverty reduction, economic diversification, and growth. These objectives, which are formally articulated in the Ninth National Development Plan (NDP 9, 2003/042008/09) depend crucially on the government's ability to attract foreign investment into nonmining areas, and to undertake the requisite structural reforms to improve the level of private sector participation in the economy. The National Strategy for Poverty (NSP), which recognizes that HIV/AIDS is both a cause and consequence of poverty, unemployment, and inequality aims to eliminate poverty in Botswana by 2016. The strategy seeks to direct antipoverty interventions at the root causes affecting income, capacity, and participation by integrating poverty reduction strategies into the medium-term economic framework. The costs of these programs are stretched further by the huge expenditure outlay required to manage the HIV/AIDS epidemic which, based on the National Strategic Framework (NSF) for HIV/AIDS, is estimated at over P 12 billion, an annual average of 5 percent of GDP in the program period. Coming at a time when diamond output is plateauing, the immediate challenge facing the government is how to finance the cost of managing the epidemic, while mitigating its adverse consequences. Effective management of the epidemic would enable Botswana to moderate the decline in human development indices and the adverse macroeconomic impact of the disease.

The NSF proffers a systematic, multisectoral approach to managing the epidemic based on prevention, care and support, management of the national response, economic impact mitigation, and a strengthened legal and ethical environment. The treatment of the epidemic will focus on the administration of antiretroviral drugs to the infected, while the treatment of tuberculosis and opportunistic sexually transmitted diseases (STDs), together with voluntary testing and counseling (VCT) are targeted at a wider audience than the HIV infected. In December 2003, Botswana signed an agreement for an $\$ 18.5$ million funding from the Global Fund for HIV/AIDS, Malaria, and Tuberculosis. A recent staff study ${ }^{3}$ shows that a successful implementation of the NSF program, reaching at least 90 percent of the a-risk group would considerably slow the decline in the growth rate of nonmining output projected in recent macroeconomic studies using the no treatment scenario. After an initial sharp decline in the program years, by 2010, the decline in nonmining output would moderate to about 4 percent. A key factor in the improved performance of nonmining output in the treatment scenario is the moderation in the decline in the population growth rate, which by 2010 is projected at 1.4 percent, compared with the no-treatment scenario of -0.9 percent. The subsequent positive trend in labor force size and its efficiency and productivity provides the necessary push for growth in nonmining output.

\footnotetext{
${ }^{1}$ Maitland MacFarlan and Silvia Sgherri, “The Macroeconomic Impact of HIV/AIDS in Botswana," IMF Working Paper 01/80 (Washington: IMF, 2001).

${ }^{2}$ Markus Haacker, "The Economic Consequences of HIV/AIDS in Southern Africa," IMF Working Paper 02/38 (Washington: IMF, 2002).

${ }^{3}$ L. F. Johnson and R. E. Dorrington, "The Demographic and Epidemiological Impact of HIV/AIDS Treatment and Prevention Programs," Mimeo, 2002.
} 
In April 2003, Botswana launched the NDP 9, which focuses on diversifying the economy away from mineral production and exports and addressing the problems of unemployment and poverty. Although the government has given the highest priority to HIV/AIDS, which is recognized as a major threat to the country's economic and social objectives, the macroeconomic framework of the plan does not explicitly include the impact of the epidemic. NDP 9 also does not consolidate HIV/AIDS expenditures, but such a consolidation is now available in the more recent National Strategic Framework for HIV/AIDS. The plan places major emphasis on improving efficiency and fostering the growth of the private sector, which is viewed as the main engine of growth.

As with previous plans, NDP 9 was the outcome of a participatory process that involved broad consultation with stakeholders in the public and private sectors, and civil society. The plan identifies potential for diversification in agriculture, tourism, financial services, and aspects of the mining industry, which the government will support through (a) funding of research; (b) an environment conducive to private sector initiative and innovation; and (c) the provision of financial assistance, to small and medium-scale enterprises and joint ventures with foreign enterprises.

The plan targets an average real GDP growth of 5.5 percent a year, which is about the same average rate achieved during the previous plan period (1997/98-2002/03). With the added boost from the proposed policies and reforms, the nonmining sectors are expected to maintain growth rates averaging 7 percent a year. Growth in the mining sector is projected to average less than $1 / 2$ of 1 percent a year, compared with the 5.3 percent achieved during the NDP 8.

\begin{tabular}{lrrrrrr}
\multicolumn{7}{c}{ NDP 9 Macroeconomic Indicators } \\
\hline & $2003 / 04$ & $2004 / 05$ & $2005 / 06$ & $2006 / 07$ & $2007 / 08$ & $2008 / 09$ \\
Real GDP growth & 5.1 & 5.9 & 6.6 & 4.9 & 5.0 & 5.4 \\
& \multicolumn{7}{c}{ (Annual Percentage Change) } \\
External current account & 3.3 & 2.4 & 4.1 & 2.5 & 1.3 & 0.9 \\
Overall budget balance & 0.3 & 0.3 & 0.4 & 0.3 & 0.2 & 0.6 \\
Public Investment Program & 10.4 & 14.0 & 15.3 & 14.9 & 14.2 & 13.8 \\
\hline Sources: Botswana, National Development Plan, 2003/04-2008/09; and staff estimates.
\end{tabular}

Sources: Botswana, National Development Plan, 2003/04-2008/09; and staff estimates.

To support the overall growth target, the investment ratio is projected to rise from 26 percent of GDP in 2002/03 to an average of 30 percent over the plan period. Foreign direct investment is projected to rise steadily to over 5 $\frac{1}{2}$ percent of GDP by $2008 / 09$ in response to additional efforts to improve Botswana's attractiveness as an investment destination. The public investment program over the six-year period is estimated at P 35.7 billion (US\$7.4 billion)

Fiscal policy will target a near budget balance as efforts will be made to enhance revenue mobilization in order to cope with (a) increased spending pressures, especially on HIV/AIDS; (b) a possible decline in SACU receipts as tariffs are reduced in the context of existing and prospective trade agreements; and (c) a slowdown in the growth of diamond revenue, as diamond production, which accounts for about 50 percent of total revenue, approaches full capacity. Revenue measures focus on the VAT, introduced in 2002, user charges, and improved tax administration. The cabinet has already approved the setting up of an autonomous Botswana Unified Revenue Service (BURS) to strengthen revenue collection. Areas of emphasis include the strengthening of tax-auditing capacity and the possible creation of a large taxpayer unit in the BURS. The cabinet has also approved a broad cost recovery program, including user fees that will become effective in 2006. Consistent with the objective of maintaining an attractive tax environment to encourage business investment, no significant changes to personal and corporate tax rates are envisaged.

Monetary and exchange rate policies will aim at maintaining low inflation and external competitiveness. The Bank of Botswana will maintain a stable exchange rate against a basket of currencies and an inflation rate no higher than the weighted-average inflation rate of Botswana's trading partners. Ongoing reforms include (a) the privatization of the public pension system, which has so far involved transfers of funds to private pension managers equivalent to 28 percent of GDP; (b) promotion of the International Financial Services Center (an offshore center); (c) issuance of government bonds aimed at fostering financial deepening; and (d) the establishment of the Financial Supervisory Authority to supervise nonbank financial institutions.

The thrust of other structural reforms under the NDP 9 would be to increase productivity by removing impediments to market efficiency. Major reforms include a relaxation of controls on prices, wages, and salaries; privatization of public enterprises and improvements in procurement and asset disposal arrangements; further market liberalization through the adoption of a competition policy; and a rural sector development strategy aimed at improving economic opportunities for rural dwellers. The authorities also intend to establish an autonomous Central Statistics Office to improve the quality and transparency of the country's statistics. 
pursued prudent macroeconomic policies and have promoted open trade and capital account regimes. Yet, the country has not been able to take full advantage of its high credit ratings to attract foreign investment and promote private sector activities outside the mining sector. Therefore, greater efforts are needed to encourage economic diversification. Moreover, policies must address the need to increase savings in light of exhaustible diamond resources, while allowing for the rising expenditure to deal aggressively with the epidemic. Against this background, structural reforms should focus on (a) reducing the scope of government and enhancing domestic resource mobilization; (b) improving the tracking of priority expenditures; (c) removing impediments to private sector development; (d) broadening access to financial services; and (e) advancing efforts with regional cooperation while seeking increasing access to foreign markets. The Botswana authorities are well aware of the country's challenges and have embraced this general approach.

6. Botswana's policies have been broadly consistent with Fund advice over the years. In this regard, the authorities have incorporated some of the HIV/AIDS programs in the NDP 9 and are working on developing a domestic deficit indicator of the fiscal stance to help guide monetary policy. In the area of statistics, Botswana is a participant in the GDDS and has made progress in implementing the recommendations of a recent ROSC mission.

\section{RECENT DEVELOPMENTS}

7. In 2003/04, productivity gains in diamond production are expected to contribute to a better-than-projected economic performance (Table 1 and Figure 2). Real GDP growth is expected to reach 5.4 percent, as automated diamond sorting led to an increase in production to 30 million carats, surpassing the original expectation by 7 percent. At the same time, private sector nonmining output growth is projected at over 5 percent for the second year in a row (Table 2). Inflation (end of period) declined from over 11 percent in 2002 to 6.4 percent in 2003, just above the Bank of Botswana's (BOB) 4-6 percent target range. This outcome reflected a prudent monetary stance and the passing of the one-time impact on prices of the introduction of the value-added tax (VAT) in 2002.

8. The overall fiscal deficit is projected to decline to below 1 percent of GDP in 2003/04, from 4 percent in 2002/03 (Table 3 and Figure 3). Total government tax revenue is expected to increase by 4.2 percentage points of GDP relative to the previous year (see Table below), owing to improvements in the collections from customs receipts from the Southern African Customs Union (SACU), ${ }^{2}$ and to the introduction of the VAT in July 2002. However, compared with the budget estimates for 2003/04, revenue, notably the VAT, is not performing fully as expected because of problems in tax administration. Total expenditure is projected to rise

${ }^{2}$ SACU comprises Botswana, Lesotho, Namibia, South Africa, and Swaziland. Customs and excise duties collected are paid into South Africa's National Revenue Fund, and the revenue is shared among members according to a revenue-sharing formula that was revised in 2002 . 
by about 1 percentage point of GDP in 2003/04, as a significant increase in current outlays on HIV/AIDS, education, and drought relief will be offset in part by lower capital expenditure (development expenditure is likely to fall short by 1.2 percentage points of GDP relative to the budget). As the government did not award a wage increase in 2003/04, the share of wages in GDP is projected to decline by 0.5 percent to 11 percent. Given the uncertain outlook for SACU tax revenue, the cabinet approved in November 2003 the introduction of an autonomous Botswana Unified Revenue Service (BURS), for which parliament is expected to approve legislation in early $2004^{3}$.

9. The government continued to draw down its deposits at the central bank as it implemented the partial privatization of the civil service pension scheme initiated in 2001. During fiscal-year 2003/04, government has transferred deposits equivalent to 8 percent of GDP in accumulated civil servant pension claims to the private pension fund managers. As of endDecember 2003, a total of 27 percent of GDP had been transferred by the government to the private sector.

10. The Bank of Botswana maintained a tight monetary policy stance through the first half of 2003 before relaxing toward the end of the year (Table 4). The bank rate was raised by a total of 100 basis points to 15.25 percent in November 2002, in order to stem inflationary pressures associated with the recent rapid growth in fiscal deficits and sharp increase in private sector credit. In addition, in 2003 the Bank of Botswana almost doubled its placements of central bank certificates (BOBCs) compared with that in 2001-the main instrument of liquidity control - to 26 percent of GDP, with a view to draining in part the increase in banking system liquidity associated with the privatization of the public service pension system. The initial issue of government bonds ( 6 percent of GDP) in 2003 contributed to a further tightening of liquidity. Partly reflecting these measures, growth in private sector credit had decelerated to 15 percent by end-2003 (from 24 percent in the previous year). As inflationary pressures abated during the year, the Bank of Botswana cautiously eased monetary policy by lowering the bank rate in steps to 14.25 percent by end-2003.

\footnotetext{
${ }^{3}$ Botswana's total public debt amounted to 14.7 percent of GDP in 2003, with the external public debt accounting for 6 percent of GDP.
} 
Central Government Operations, 2000/01-2003/04 1/

(In percent of GDP)

\begin{tabular}{|c|c|c|c|c|c|c|c|}
\hline & 1998/99 & 1999/00 & $2000 / 01$ & $2001 / 02$ & $2002 / 03$ & $\begin{array}{r}2003 / 04 \\
\text { Budget } \\
\end{array}$ & $\begin{array}{l}\text { 2003/04 } \\
\text { Rev.Est. }\end{array}$ \\
\hline Total revenue and grants & 36.2 & 49.7 & 50.9 & 40.8 & 41.9 & 47.2 & 46.1 \\
\hline Of which tax revenue & 26.6 & 41.3 & 43.5 & 34.0 & 35.9 & 40.9 & 39.7 \\
\hline Of which mineral revenue & 15.0 & 27.8 & 30.2 & 22.4 & 21.9 & 21.9 & 21.9 \\
\hline $\mathrm{SACU}^{2 /}$ receipts & 6.0 & 8.0 & 7.9 & 5.6 & 4.6 & 5.7 & 6.1 \\
\hline Total expenditure and net lending & 42.3 & 43.3 & 41.6 & 43.9 & 45.9 & 46.7 & 46.8 \\
\hline Current expenditure & 29.1 & 29.3 & 30.2 & 31.9 & 33.9 & 35.9 & 37.2 \\
\hline Of which: wages and salaries & 10.2 & 10.0 & 9.9 & 12.6 & 11.5 & 11.1 & 11.1 \\
\hline Capital expenditure & 13.9 & 14.3 & 11.3 & 11.9 & 11.2 & 11.9 & 10.8 \\
\hline Overall surplus or deficit (-) & -6.0 & 6.4 & 9.3 & -3.1 & -4.1 & 0.6 & -0.7 \\
\hline
\end{tabular}

11. The external current account surplus is expected to have narrowed slightly to 11 percent of GDP in 2003 (Table 6), as the surge in diamond exports was offset by strong import growth (associated with the large budget deficit in 2002/03 and the appreciating pula), and a higher repatriation of profits and dividends. Since mid-2001, the major currencies (the SDR and the rand) in the basket to which the pula is pegged have undergone a major realignment contributing to the 12 percent appreciation of the nominal effective exchange rate (NEER) through October 2003 (Figure 4). ${ }^{4}$ In the comparable period, partly reflecting the relatively higher inflation in Botswana, the real effective exchange rate (REER) appreciated by about 19 percent, contributing to some loss of external competitiveness for Botswana. Partly to correct for this development, effective February 6, 2004, the pula was devalued by 7.5 percent against the currency basket. Following a significant decline in 2002, net international reserves declined further by US $\$ 200$ million during 2003 to a level of US\$5.3 billion by year's end ( 25 months of imports). The loss in reserves is associated with the transfer of civil service pension claims to private fund managers referred to above.

\section{REPORT ON DISCUSSIONS}

12. The NDP 9 indicates that the government's overriding objectives are maintaining macroeconomic stability, promoting economic diversification, and addressing the HIV/AIDS epidemic. As the mission concurred with the thrust of these objectives, the policy discussions focused on ways to implement and support the authorities' economic strategy. With

\footnotetext{
4 The authorities' calculations of the NEER and the REER, which are based on the currency basket weights, indicate appreciation of 6.1 percent and 15 percent, respectively" over the same period.
} 
diamond production reaching full capacity, it was imperative to save now. Thus, fiscal prudence emerged as a key issue, given that slowing economic growth, diversification efforts, and the HIV/AIDS epidemic are likely to place a heavy burden on the budget. At the same time, discussions on monetary and exchange rate policies focused on external competitiveness and reforms to strengthen monetary management. Complementary NDP 9 structural reforms to stimulate private sector development also emerged as important actions to support the government's objective of diversifying the economy.

13. The economic outlook for $\mathbf{2 0 0 4 / 0 5}$ is for moderate growth and subdued inflation. Real GDP growth is projected at about 4 percent, supported by the continued strong performance of the construction and service sectors. Inflation (end of period) is expected to remain at about $6 \frac{1}{2}$ percent, reflecting the impact of the recent devaluation and the continuation of a prudent monetary stance. The mission urged the authorities to remain vigilant as domestic demand pressures may emerge in the period leading to the elections, owing to a possible increase in government spending (a 15 percent wage increase for public sector employees has been announced by the government). ${ }^{5}$

\section{A. Economic Prospects}

\section{The staff has prepared a medium-term macroeconomic scenario based on the} policies envisaged in the NDP 9. The scenario points to a slowdown in economic growth, which, in turn, is expected to lead to a deterioration in the fiscal and external current account balances relative to the past decade. Real GDP growth is projected to average about $3 \frac{1}{2}$ percent a year during the 2003/04-2008/09 period, compared with about 6 percent a year in the 1990s because of the plateauing of diamond production and the HIV/AIDS epidemic (see Table below and Table 7). The fiscal projection indicates that the government's operations will be in deficit for the period through 2008/09, compared with an average surplus of $2 \frac{1}{2}$ percent of GDP in the late 1990s. However, the downside risks of this scenario are sizable because of the still uncertain (but possibly significant) budgetary implications of additional HIV/AIDS spending included in the NSF, which has not been incorporated in the NDP 9. Under the staff's baseline scenario, the external current account surplus is expected to narrow from 10-11 percent of GDP in the 19972003 period to 2-3 percent over the medium term, as diamond production reaches its full capacity and imports relating to the HIV/AIDS program, food, and intermediate goods continue to rise.

\footnotetext{
${ }^{5}$ The 15 percent public sector wage increase was announced in November 2003, following the recommendation of a commission appointed in 2001 to review the structure of public sector salaries. The increase will become effective in April 2004.
} 
Staff's Medium-Term Baseline Scenario, 1997-2008

\begin{tabular}{|c|c|c|c|c|c|c|c|c|}
\hline & $\begin{array}{c}\text { Average } \\
1997-2001\end{array}$ & 2002 & 2003 & 2004 & 2005 & 2006 & 2007 & 2008 \\
\hline National income and prices & \multicolumn{8}{|c|}{ (Annual percentage changes, unless otherwise indicated) } \\
\hline Real GDP 1/ & 5.9 & 5.5 & 5.4 & 3.8 & 3.6 & 3.6 & 3.6 & 3.4 \\
\hline of which: private nonmining GDP growth & 5.2 & 5.6 & 5.2 & 5.0 & 4.8 & 4.7 & 4.7 & 4.3 \\
\hline Output from mining/GDP 1/ & 34.3 & 34.7 & 35.0 & 34.4 & 33.9 & 33.3 & 32.8 & 32.4 \\
\hline Nominal GDP (in billions of pula) 1/ & 25.5 & 34.9 & 38.2 & 41.5 & 44.9 & 48.4 & 52.3 & 56.1 \\
\hline Consumer prices (average) & 7.7 & 8.0 & 9.3 & 6.5 & 6.4 & 5.8 & 5.3 & 5.0 \\
\hline & \multicolumn{8}{|c|}{ (In percent of GDP, unless otherwise indicated) } \\
\hline Overall fiscal balance (including grants) $2 /$ & 2.3 & -4.1 & -0.7 & -1.1 & -0.3 & -1.0 & -0.6 & -0.3 \\
\hline External current account balance (deficit -) 3/ & 10.4 & 11.6 & 11.0 & 6.4 & 5.7 & 3.7 & 2.9 & 1.7 \\
\hline Public debt / GDP 3/ & 9.3 & 8.7 & 14.7 & 13.4 & 12.4 & 11.6 & 10.8 & 10.1 \\
\hline Gross official reserves (in months of imports) & 30.7 & 30.8 & 23.2 & 20.9 & 20.7 & 20.1 & 19.3 & 18.4 \\
\hline
\end{tabular}

15. The NDP 9, however, envisages higher growth than projected by the staff. Specifically, the NDP 9 assumes real GDP growth of 5.5 percent a year over the medium term, owing to more optimistic assumptions regarding the impact of HIV/AIDS on growth. The mission urged the authorities to integrate the NSF and NSPR into an updated NDP 9 macroeconomic framework in order to provide a more realistic basis for an appropriate policy response. The authorities explained that both the NSF and NSPR had to be formally adopted and approved by parliament before they could be integrated into the NDP 9. They indicated that some of the NSF programs had been included in the NDP 9 through ministerial budget submissions but agreed with the staff on the need to formally integrate all the programs into the budgetary framework. To that end, the authorities requested Fund technical assistance to expedite the exercise.

\section{B. Fiscal Policy}

16. The discussions on fiscal policy took place against the backdrop of indications that the government's operations in 2003/04 might result in an overall deficit for the third consecutive year, compared with the government's announced intention to return to a longstanding tradition of surpluses. Some revenue items, notably the VAT, are expected to show a sizable shortfall owing in part to weak tax administration, while expenditures on HIV/AIDS and drought relief would exceed initial expectations. The staff observed that, unless timely measures were taken, budget deficits would continue in the medium term even under the optimistic fiscal assumption made in the NDP 9, and the desired public savings would not be realized (Table 8). In this connection, the staff stressed the need for action both on revenue and expenditures to avoid putting undue pressures on domestic interest rates.

17. The authorities acknowledged that the fiscal performance so far in $2003 / 04$ had been weaker than originally envisaged, but they expressed confidence that the original objective of a small budget surplus would be attained. To that end, levies on petroleum products were raised, and short-term measures, mainly associated with the administration of the VAT, were introduced to improve collections. Moreover, capacity constraints would likely 
contribute to a shortfall in capital expenditure. The mission welcomed these efforts as helpful but noted that, in any event, a small overall deficit was likely to emerge in 2003/04. It urged the authorities to consider more enduring measures in the 2004/05 budget and beyond in order to place the budget on a stronger footing.

18. The discussions of the $\mathbf{2 0 0 4 / 0 5}$ budget were limited, as the authorities were in the midst of budget negotiations. Staff estimates, incorporating the announced 15 percent wage increase, projected a slight increase in the overall deficit to about 1 percent of GDP. The staff explained that this outturn could be optimistic in light of likely expenditure pressures during an election year and growing HIV/AIDS expenditure. The authorities indicated that they would aim to achieve a small surplus as a result of the new revenue measures and a policy of expenditure restraint.

\section{The authorities agreed with staff on the need to boost nondiamond revenue and} strengthen the medium-term budget outlook. The traditional sources of revenue growth face constraints. Specifically, revenue from diamonds would plateau in line with production, the government's share of central bank profits would decline, owing to the impact of the privatization of the civil service pension scheme, and SACU revenue is expected to show modest nominal increases over the medium term. Accordingly, the authorities recognized that the scope for increasing revenue in the medium term hinged largely on improving the yield from the VAT, the personal income tax, and corporate income taxes. The authorities hoped for quick action by parliament to strengthen the relevant legislation for these taxes. The staff welcomed these efforts; it also stressed the need to make the BURS lean and efficient, and to empower it with strong auditing and enforcement capacity, including through the establishment of a unit for large taxpayers. Follow-up measures would entail the merging of the VAT and income tax administration.

20. The authorities and staff agreed that the recent growth in current expenditure had made it difficult for the government to adhere consistently to Botswana's traditional fiscal rule. ${ }^{6}$ The sharp growth in overall budgetary expenditure (to 47 percent of GDP in 2003/04) was not sustainable, especially taking into account future expenditure pressures related to HIV/AIDS. The mission argued that the fiscal rule needed to be refined to reflect the growing emphasis on domestic tax revenue (in particular, the VAT) and ongoing pressures to increase outlays on

\footnotetext{
${ }^{6}$ An informal rule followed by the authorities provides for mineral revenues to cover "investment expenditure," defined as development expenditure and recurrent expenditure on education and health, with all other recurrent expenditure being funded from nonmineral receipts. Under this rule, Botswana generated successive budget surpluses and built up substantial external reserves. With faltering diamond exports and revenue, higher expenditure on HIV/AIDS, and pressures on other recurrent outlays (especially on wages), the fiscal rule and the overall budget balance have been under pressure. This has been mitigated in part by lowering development expenditure.
} 
education and health, including HIV/AIDS (Figure 3). More important, there is a need to strengthen the scrutiny of expenditure priorities and exert greater control to slow the overall growth in public outlays. As part of this effort, the staff recommended improving expenditure classification, so that the tracking of consolidated programs could reflect the NDP 9 priorities in the social sectors, especially on HIV/AIDS. The authorities explained that the rising expenditure on education reflected mainly the increased role of government in supporting programs at the tertiary level.

21. The authorities indicated that they were working on other measures to strengthen revenue and increase expenditure efficiency, while providing adequate safeguards for continued access to public services by the poor. The cabinet approved user fees in education, a unit was set up to review user service charges in ministries and government departments, and water rates and connection charges were increased by 23 percent in December 2003. However, most of the new or increases in user charges will come into effect in 2006. Also, expenditure ceilings are being tightened across the board to induce government agencies to improve efficiency, and a planned civil service reform, which is to be implemented in phases beginning in 2004, is expected to generate additional savings. Following the mission, the authorities requested Fund technical assistance to help them improve budget classification and the tracking of social expenditures.

22. The staff also called for a close monitoring of development expenditure. In this regard, the staff stressed that, against the background of increased pressure on recurrent outlays, there was little or no room for upward adjustments in the capital program as had happened under the Eight National Development Plan (NDP 8), when actual project costs had doubled the budgeted amounts. In addition, the staff also urged the authorities to identify areas where expenditure cutbacks could be made without jeopardizing the growth objectives during the plan period. The authorities indicated that they had learned important lessons from their experience under the NDP 8, and that they now approached the estimation of project costs more realistically. Experience had also been gained in estimating the operating and maintenance costs of projects, and emphasis would be placed on completing ongoing projects, as distinct from initiating new ones. Moreover, the authorities agreed with staff that a clearer link between the annual budgets and the NDP 9 should enhance the credibility of the government's program and the coordination of macroeconomic policies. Establishing this would require, among other things, the dissemination, with sufficient details, of the annual revised macroeconomic framework of the NDP 9.

\section{Monetary and Exchange Rate Policies}

\section{Monetary policy is anchored by a peg to a basket of currencies comprising the}

rand and the SDR. The policy aims to support the national objectives of economic diversification and export competitiveness, by attempting to keep the NEER of the pula broadly stable. Because the weight of the rand is greater in the basket peg than South Africa's trade weight, the strength of the rand has led to an appreciation of the pula in nominal effective terms over the past several years. Thus, there appears to be a good case for reexamining the currency basket, with a view to aligning it closer to a trade-weighted composition. The recent devaluation 
of the pula partly offset the real effective appreciation registered over the last several years. Given the continued growth in the nondiamond mineral and services exports the staff is of the view that the current level of the exchange rate is broadly appropriate and can be sustained by fiscal consolidation. The discussions on competitiveness with the authorities focused on broader issues affecting Botswana's prospects for economic diversification, including the need to maintain a prudent fiscal policy and to press ahead with pending structural reforms (see Subsection E on structural reforms).

24. The central bank also sets an inflation target range based on the average inflation rate in trading-partner countries, and this range is expected to remain broadly unchanged following the recent devaluation. ${ }^{7}$ However, the role played by higher domestic inflation than the average in trading partner countries in generating a real effective appreciation of the pula over the last several years, suggests a more ambitious inflation target in order to sustain the exchange rate policy. For 2004/05, staff projects broad money growth of 12-14 percent, which, based on the staff's preliminary fiscal projections, should accommodate a 9.5 percent growth in private sector credit. Botswana's interest rates, both in nominal and real terms, are significantly above those in the region. ${ }^{8}$ As noted above, the authorities cut the bank rate in steps to 14.25 percent in December 2003, in light of slower growth in private sector credit and lower domestic and regional inflation. While there may be some scope for further reducing interest rates, the mission concurred with the authorities' cautious approach, given the uncertainty about the fiscal situation. In this regard, the mission emphasized that the feasibility of reducing the relatively high real interest rates depended ultimately on containing the rapid growth in government spending, which had averaged 16 percent per annum over the last three years. The authorities also recognized that, with the ongoing financial sector reforms and the eventual loss of monetary independence, the current exchange rate regime would need to be supported by appropriately tight credit policies.

25. The authorities are implementing a number of reforms to strengthen the conduct of monetary policy. The mission supported the reforms by the central bank to (a) introduce greater transparency in monetary management; (b) enhance its understanding of the policy transmission mechanism; and (c) improve the functioning of the money market and the effectiveness of monetary policy. The impetus for these reforms stems in part from (a) the large transfer of financial resources from the government to private fund managers; (b) the establishment of an International Financial Services Center (IFSC) which operates offshore; and

\footnotetext{
${ }^{7}$ Under the current peg system, the central bank retains some monetary independence because financial markets are not adequately developed to permit full arbitrage. This situation is, however, not likely to persist for long, given various ongoing reforms by the authorities (see paragraph 25).

${ }^{8}$ Since mid-2002, South Africa has gradually reduced interest rates. The repurchase rate was brought down in stages to the current rate of 8 percent in December 2003 from a high of 13.5 percent in September.
} 
(c) the recent introduction of government bonds. ${ }^{9}$ The success of these reforms hinges, however, on a better coordination of macroeconomic policies and improvements in data availability (see below). The authorities have also started to take steps, with Fund technical assistance, to enhance inflation modeling.

\section{The banking system appears broadly sound, and supervision of the sector is}

generally adequate. Banks maintain a capital adequacy ratio of 15 percent or above, and the proportion of nonperforming loans is small (see Table below). However, a sizable number of nonbank financial institutions (NBFIs), including some that operate in the offshore center and the private pension funds, are not adequately supervised by a regulatory body. ${ }^{10}$ Given the concerns about money laundering and considering the size of the pension funds, there is an immediate need to reform the existing prudential framework. The authorities explained that they had initiated a review of the 1987 Pensions Act and were planning to revise the Stock Exchange Act. They are also reviewing the existing legislation on AML to determine if a separate AML law is needed. The authorities followed up with a request for Fund technical assistance to set up an autonomous Financial Supervisory Authority to regulate and supervise the NBFIs.

Financial Soundness Indicators, 1998-2003 1/

(In percent, unless otherwise indicated)

\begin{tabular}{|c|c|c|c|c|c|c|}
\hline & 1998 & 1999 & 2000 & 2001 & 2002 & 2003 \\
\hline \multicolumn{7}{|l|}{ Commercial Banks } \\
\hline Regulatory capital to risk-weighted assets 2/ & 16.0 & 17.2 & 27.1 & 27.6 & 20.2 & \\
\hline Past due advances (NPL) to total advances 3/ & 2.4 & 3.9 & 1.7 & 4.1 & 3.5 & .. \\
\hline Loan loss provisions to nonperforming loans & 43.5 & 58.2 & 96.1 & 118.3 & 131.8 & 179.6 \\
\hline Return on average assets & 3.3 & 3.4 & 3.9 & 4.0 & 4.3 & .. \\
\hline Return on equity & 43.1 & 46.4 & 37.7 & 40.6 & 43.8 & - \\
\hline Interest income to gross income & 77.2 & 79.6 & 79.3 & 78.2 & 77.4 & .. \\
\hline Liquid assets to total assets & 29.5 & 27.5 & 21.5 & 23.7 & 19.6 & 20.1 \\
\hline Total advances to deposits & 53.9 & 60.3 & 70.5 & 57.7 & 71.4 & 72.0 \\
\hline
\end{tabular}

Source: Bank of Botswana Annual Report (2001), the Banking Supervision Annual Report (2002),

and theBank of Botswana Financial Statistics (2003).

1/ For 2003, data as of end September.

2/ Average capital adequacy ratio of banks in Botswana.

3/ Arrears on loans and advances over 6 months. From 2001, due to the change in reporting requriements, the figures are loans over 90 days.

${ }^{9}$ The introduction of 2- 5- and 12-year government bonds in 2003 has allowed for the derivation of a domestic yield curve. The government plans to list the bonds on the Botswana Stock Exchange (BSE).

${ }^{10}$ Responsibility for regulating and supervising banks lies with the central bank, whereas the NBFIs currently fall under the Ministry of Finance and Development Planning, which has a limited capacity to supervise them. 


\section{Medium-Term External Outlook}

27. Consistent with the staff's medium-term baseline scenario (which assumes a 2 percent annual increase in diamond prices), Botswana's external current account surpluses are projected to decline progressively from 11 percent of GDP in 2003 to 1.7 percent in 2008 (Table 9). The growth rate of exports is expected to lag behind that for imports, owing to a maturing diamond sector and the need for higher expenditures on HIV/AIDS and social infrastructure. Tourism receipts are expected to show robust growth, reflecting this sector's potential and the high priority attached to it in the NDP 9. The capital and financial account would register progressively smaller deficits over the medium term, an outcome that can be attributed mostly to the gradual decline in portfolio investments abroad, related, in turn, to the transfer of pension funds to private managers. ${ }^{11}$ Gross official reserves are projected to increase slowly to about US\$ 6 billion by 2008, which would imply a fall in coverage to below 20 months of imports.

28. In view of the uncertainty about the impact of the HIV/AIDS expenditure on the budget and Botswana's high dependency on diamonds, the staff prepared two alternative medium-term scenarios to assess the downside risks associated with outcomes in these areas, that differ from the baseline scenario. The first alternative scenario is illustrative and reflects an attempt to incorporate the additional expenditures on HIV/AIDS envisaged in the NSF into the staff's medium-term baseline scenario. ${ }^{12}$ Based on this exercise, the overall fiscal deficit would likely increase more rapidly and reach about 7 percent of GDP by 2008 compared with a balanced budget in the baseline scenario (Tables 7 and 8). In the absence of additional measures, financing these large deficits would require a draw-down of government deposits which would, in turn, lead to a drop in international reserves to about 16 months of imports by 2008, compared with 18 months of imports in the baseline scenario (Table 9). This situation highlights the need

${ }^{11}$ Existing regulations oblige pension funds to invest at least 30 percent of their holdings in the domestic market, thus allowing up to 70 percent of the total assets to be invested abroad.

Although, following the reform, there was an immediate capital outflow, the asset managers are still holding domestic assets far above the required minimum levels because of the relatively high rates of returns on pula-denominated assets.

12 The projections are based on the following simplifying assumptions: (a) the Ministry of Health accounts for the bulk of HIV/AIDS expenditure; (b) since there is no consolidated budget line item for HIV/AIDS expenditure in NDP 9, the staff derived such expenditure as the deviation of the projected total health spending from its historical trend; (c) donor funding will account for 30 percent of the projected NSF HIV/AIDS programs: and (d) the government will abide by the commitment to fully implement the ARV drug program. The difference between the projected NSF HIV/AIDS expenditure and the derived outlays for the epidemic in the NDP 9 comprise the additional HIV/AIDS expenditure that was incorporated in the staff's medium-term budget projections. 
for fiscal adjustment by more rigorous control on expenditure growth and stepping up efforts to mobilize additional domestic revenue and donor support.

29. The second alternative scenario assumes a fall in diamond prices of 5 percent relative to the baseline. Under this scenario, the external current account surplus would drop from 11 percent of GDP in 2003 to 5.6 percent in 2004 and would shift into deficit starting in 2007. As a result, international reserves would decline to 15 months of imports of goods and services by 2008 , compared with 20 months under the baseline projections. Reflecting the decline in diamond revenue, the government's budget would shift into deficits close to 3 percent of GDP by 2008/09. The Botswana authorities agreed with the staff that the economy was highly vulnerable to terms of trade shocks and that diversifying the export base was essential to maintaining high growth and a strong external position. They noted that recent trade agreements should have a positive impact on economic activity over the next few years, both through better access for Botswana's exports to foreign markets and added incentives for foreign direct investment.

30. Both public and external debt under the staff's baseline scenario and under the alternative scenario 2 ( 5 percent fall in the diamond prices relative to the baseline) appear to be sustainable under all the shocks considered (Tables 10 and 11).

\section{E. Structural Reforms and Statistical Issues}

31. The authorities recognized that, notwithstanding Botswana's attractiveness as an investment destination (low tax rates, zero tolerance for corruption, and absence of controls on current or capital transactions), ${ }^{13}$ foreign direct investment had been concentrated in the mining sector (over 75 percent over the last decade). This is partly explained by the fact that the country is sparsely populated and landlocked, and has high transportation costs and a shortage of skilled labor.

32. The structural reforms envisaged under the NDP 9 provide a basis for promoting economic diversification. The reforms are targeted at supporting private sector-led investment, especially in the nonmining sector. Complementing the push for private pension funds and establishment of the IFSC, efforts are concentrated in removing the remaining barriers to investment and reforming the legal and institutional framework. To this end, the authorities have benefited from technical assistance from IFC staff members, who have made recommendations to expedite residence and work permits for expatriates and to improve access to land, including

\footnotetext{
${ }^{13}$ The maximum personal and corporate marginal tax rate is 25 percent; the VAT rate is 10 percent, and investors can freely repatriate profits and dividends. Botswana was also ranked as the leading African country in 2003 in the public institutions index of the World Economic Forum's Executive Survey, which evaluates, among other things, judicial independence, property rights, and corruption.
} 
serviced plots (with utilities) and factory spaces. Moreover, draft legislation on foreign direct investment and industrial development, as well as an update of the Companies Act, is being prepared to modernize and streamline the legal framework. The authorities have also set up a one-stop investment center and the Botswana Export Development and Investment Authority to help expedite projects in five key nontraditional export sectors. ${ }^{14}$ The mission welcomed these efforts and urged the authorities to move ahead with the privatization of public enterprises, the outsourcing of certain government services, and the implementation of complementary regulatory reforms.

33. Botswana is a member of the Southern African Customs Union (SACU). ${ }^{15} \mathrm{SACU}$ is engaged in negotiations with the United States on a free trade agreement and is also pursuing economic partnership agreements with the European Union, along with the African, Caribbean, and Pacific (ACP) countries. Negotiations are also ongoing on the possible extension of the preferential treatment granted under the U.S. African Growth and Opportunity Act (AGOA) through 2008. Botswana is also implementing the Southern African Development Community (SADC) Protocol on Trade and the new SACU Agreement, signed in October 2002. ${ }^{16}$ The mission encouraged the authorities to move rapidly to implement these reforms, as well as complementary measures, to enhance foreign direct investment that would maximize the benefits offered through regional cooperation.

34. Botswana's statistics are generally adequate for surveillance purposes, and the country is a participant in the General Data Dissemination System (GDDS); however, the availability of some macroeconomic data remains subject to significant lags. The mission

\footnotetext{
${ }^{14}$ These include (a) the garment/textile industry, to take advantage of Botswana's eligibility under the U.S. African Growth and Opportunity Act (AGOA); (b) the leather industry, to utilize a large amount of by-products from the beef export industry: (c) the glass industry, which can benefit from the availability of soda ash mining; (d) the tourism industry, which has substantial potential, especially in the Okavango Delta; and (e) the information technology industry, which would benefit from investments in the fiber-optic network, including the planned call centers within the IFSC project.

15 The SACU's simple average external tariff is 11.4 percent (2003), compared with an average of 17.6 percent for Africa and a world average of 12.4 percent. On the 1-10 scale in the Fund's index of trade restrictiveness (10 being most restrictive), SACU rates a relatively open tariff system. However, taking into account the nontrade barriers (NTBs), SACU ranks " 5 ". In the case of Botswana, the NTBs comprise state monopoly on beef exports (currently under review), import permits for certain agricultural products, and seasonal agricultural bans.

${ }^{16}$ Under the SADC Protocol on trade, SACU countries grant duty-free access on a reciprocal basis to imports from SADC members. The agreement calls for the establishment of a free trade area in southern Africa by 2008.
} 
conducted an update of a data Report on Observance of Standard and Codes (ROSC) concluded in October 2001. It found that progress had been made in some areas but stressed the importance of improving timeliness in compiling national accounts, trade, and labor market data. The mission also encouraged the authorities to synchronize the accounting periods for the government sector, the national accounts, and the balance of payments statistics. Progress in these areas was considered critical to improve the coordination of macroeconomic policies. The authorities concurred with the mission's recommendations and indicated that, as part of ongoing reforms, they planned to establish an autonomous Central Statistics Office (CSO) with adequate resources and a clear mandate to compile and disseminate timely information. The authorities have requested Fund assistance in this area.

35. The authorities confirmed their commitment to eliminate the multiple currency practice that stems from the Foreign Exchange Risk-Sharing Scheme (provided by the central bank to cover certain public enterprise loans), which was abandoned in 1990. The practice would end in 2006 when the last arrangement under the scheme expires.

\section{StafF ApPraisal}

36. Botswana's economy faces major challenges in adapting to the plateauing of diamond production - hitherto the main engine of growth-and the HIV/AIDS epidemic, which threaten to undermine the remarkable progress achieved in the past. Moreover, policies must address the tension arising from the need to deal with exhaustible diamond resources via greater savings, on one hand, while sharply increasing expenditure growth because of the epidemic on the other. In response, the authorities have prepared a medium-term strategy through the Ninth National Development Plan (NDP 9), which is complemented by the National Strategic Framework (NSF) and National Strategy for Poverty Reduction (NSPR).

37. The staff concurs with the thrust of the authorities' broad strategy. The formulation of frameworks to deal with the epidemic, encourage economic diversification, and further reduce poverty constitutes an important first step to deal with the country's challenges. However, these efforts need to be followed up with a full integration of the NSF and the NSPR into the macroeconomic framework of the NDP 9. This exercise will facilitate the updating of the medium-term macroeconomic framework to inform an appropriate policy response. Furthermore, a decisive implementation of supporting structural reforms, some with Fund technical assistance, is crucial to broaden and sustain growth.

\section{The authorities have been successful, with the benefit of technological} improvements in diamond production, in maintaining moderate growth and low inflation. However, the fiscal outlook is uncertain, owing to possible expenditure pressures during the preelection period, including the impact of the salary increase associated with the reform of civil service pay structure, as well as of the growing HIV/AIDS-related expenditure. Maintaining a prudent fiscal stance is crucial to avoid putting undue pressures on domestic interest rates. 
39. The slowdown in economic growth related to the approach of full capacity in diamond production is expected to lead to a deterioration in fiscal and external current account balances from the past several years, even under optimistic assumptions. Moreover, if the NSF-projected expenditure on HIV/AIDS is fully taken into account, the pressure on the budget and external balances could be even greater. Against this background, the staff urges the authorities to expedite reforms to strengthen tax administration, especially for the VAT, by establishing an autonomous revenue authority with strong audit and enforcement functions, and a unit to control large taxpayers.

40. On the expenditure side, a timely incorporation of the HIV/AIDS and poverty reduction-related expenditure into the budget framework is urgently needed so that an appropriate analysis can be conducted to underpin corrective measures. These measures should include a refinement of the fiscal rule (which earmarks diamond revenue to development expenditure) by taking into account the changing composition of revenue and expenditure. Moreover, a prompt reassessment of expenditure priorities is needed to contain the rapid growth of government expenditure. In this context, the staff encourages the authorities to advance with the introduction of user fees, including for tertiary education, and to adjust utilities charges as needed. As part of this exercise, it will be important to ensure that the poor and vulnerable groups are adequately protected.

41. The major realignment in the currencies that comprise the basket to which the pula is pegged has resulted in some appreciation of the pula in real effective terms, which was partly offset by the recent devaluation of the currency. The staff believes that the current level of the exchange rate is broadly appropriate but needs to be supported by a tight fiscal policy. Moreover, the staff believes that there is a good case for reexamining the basket composition with a view to bringing it closer to a trade-weighted composition. The authorities are implementing a number of structural reforms to help maintain Botswana's external competitiveness and promote diversification. These reforms should be accompanied by a prudent fiscal stance in order to support the pegged exchange rate regime and avoid a loss of external competitiveness. It is also important that the structural reforms and regional efforts to improve the access to export markets be complemented with decisive steps to privatize public enterprises and outsource certain government services.

42. Inflation has moderated and is close to the central bank target. However, the staff believes that a more ambitious inflation target is needed to maintain external competitiveness while sustaining the current exchange rate peg. In the meantime, domestic interest rates in Botswana are relatively high, and while there might be some scope for a reduction, the authorities' cautious approach is appropriate, given the uncertain fiscal situation. The staff would also encourage the authorities to improve the coordination of fiscal and monetary policies so as to facilitate lower interest rates (more in line with those in the region) and foster private sector activities. Looking ahead, with the ongoing financial sector reforms and the eventual loss of monetary independence, the current exchange rate regime would need to be supported by appropriately tight domestic credit policies. The authorities are taking steps to strengthen the effectiveness of monetary policy, including through improved inflation modeling. The staff 
supports these efforts and notes that they should be complemented with improvements in the timeliness and availability of financial data.

43. Financial sector reforms in Botswana form an important part of the diversification strategy, but they pose a challenge for the financial sector. The civil service pension reform and the introduction of an offshore financial service center have the potential to significantly broaden and deepen the sector, but they also introduce new risks that call for strengthened supervision of nonbank financial institutions. The staff is encouraged by the authorities' recent request for Fund technical assistance in this area.

44. Botswana has made progress, in the context of its participation in the GDDS improving macroeconomic data. While such data are generally adequate for surveillance purposes, further improvements in the quality and timeliness of the national accounts, the prices statistics, and key trade data are required. The staff would encourage the authorities to intensify their efforts to address data problems and eventually set up an autonomous CSO, including with Fund technical assistance. The CSO should have adequate resources and a clear mandate to disseminate timely macroeconomic and social data.

45. The staff notes the authorities' intention to eliminate by 2006 the multiple currency practice arising out of the Foreign Exchange Risk-Sharing Scheme (FERS), which was abandoned in 1990. In light of the authorities' intention to eliminate by 2006 the multiple currency practice arising from the FERS, the staff recommends that the Board approve the retention of this measure until March 31, 2005 or the conclusion of the next Article IV consultation with Botswana, whichever is earlier.

46. It is recommended that Botswana remain on the 12-month consultation cycle. 
Figure 1. Botswana and Selected Countries: Per Capita GDP, 1980-2003 (In U.S. dollars)

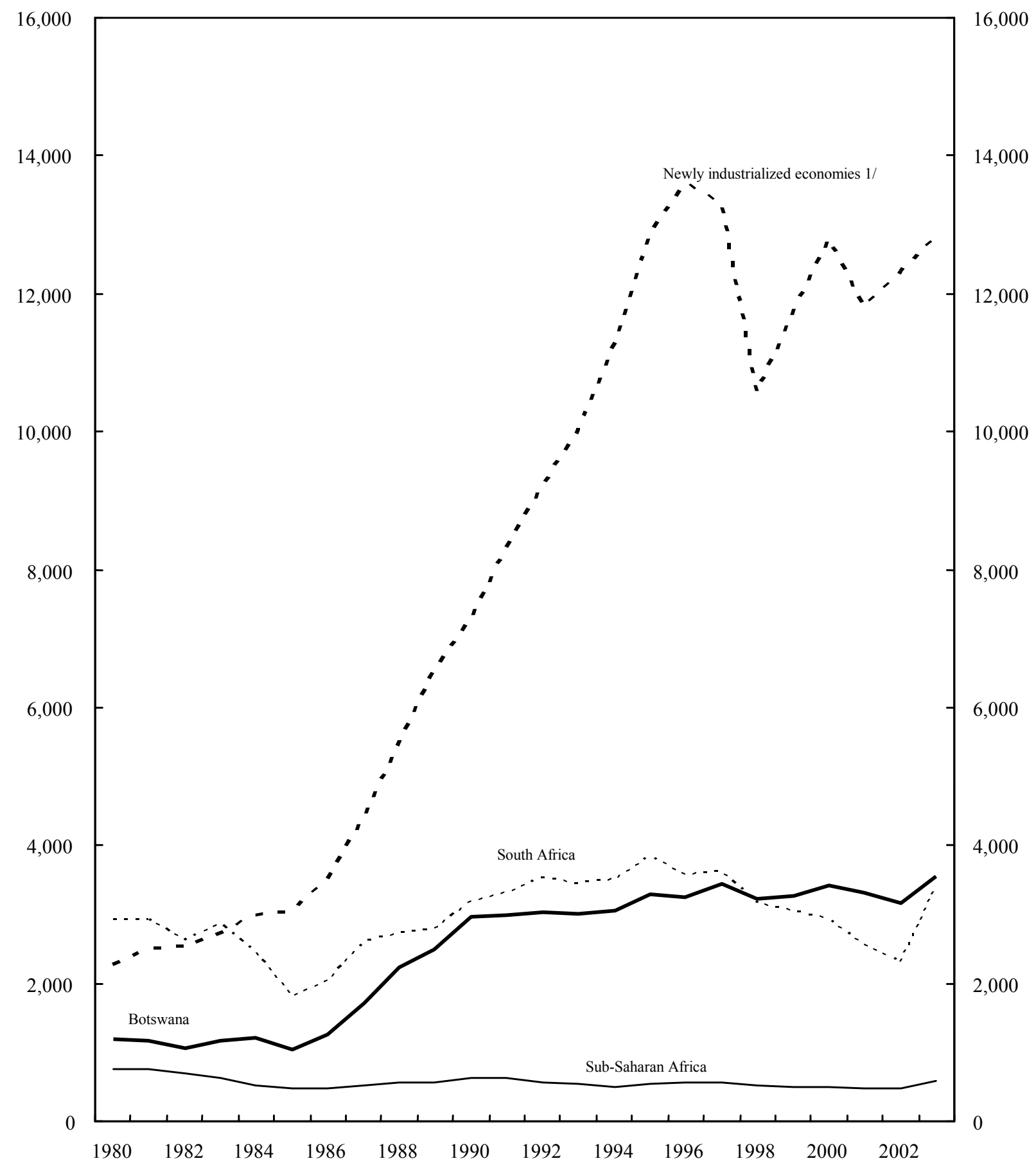

Source: World Economic Outlook database.

1/ Hong Kong SAR, Taiwan Province of China, Korea, and Singapore. 
Figure 2. Botswana: Main Economic Indicators, 1990-2003
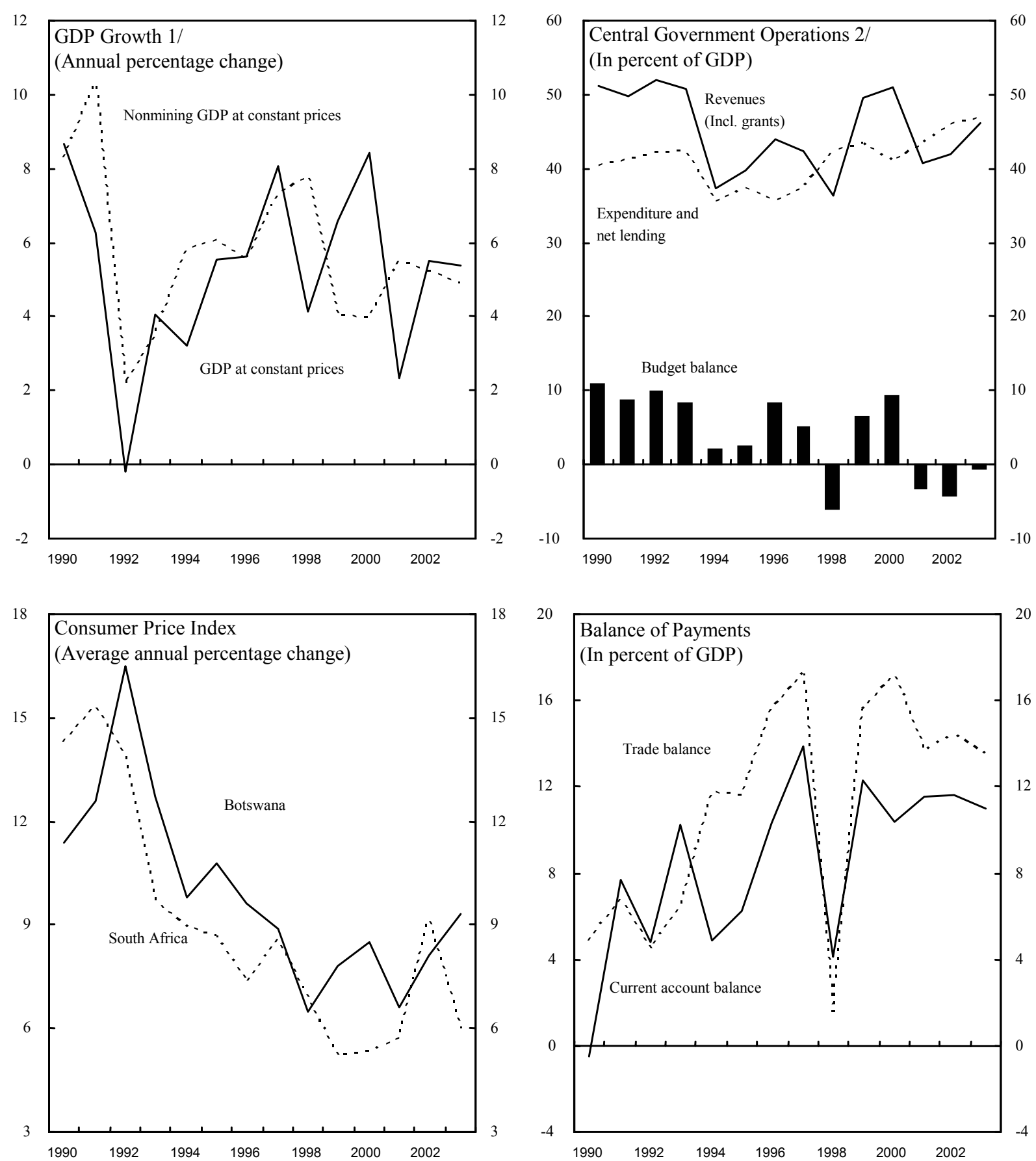

Sources: Botswana authorities; and Fund staff estimates.

1/ National accounts year beginning July 1 .

2/ Fiscal year beginning April 1. For 2003/4, the figures represent the government budget. 
Figure 3. Botswana: Selected Fiscal Indicators, 1996/97-2003/04 1/
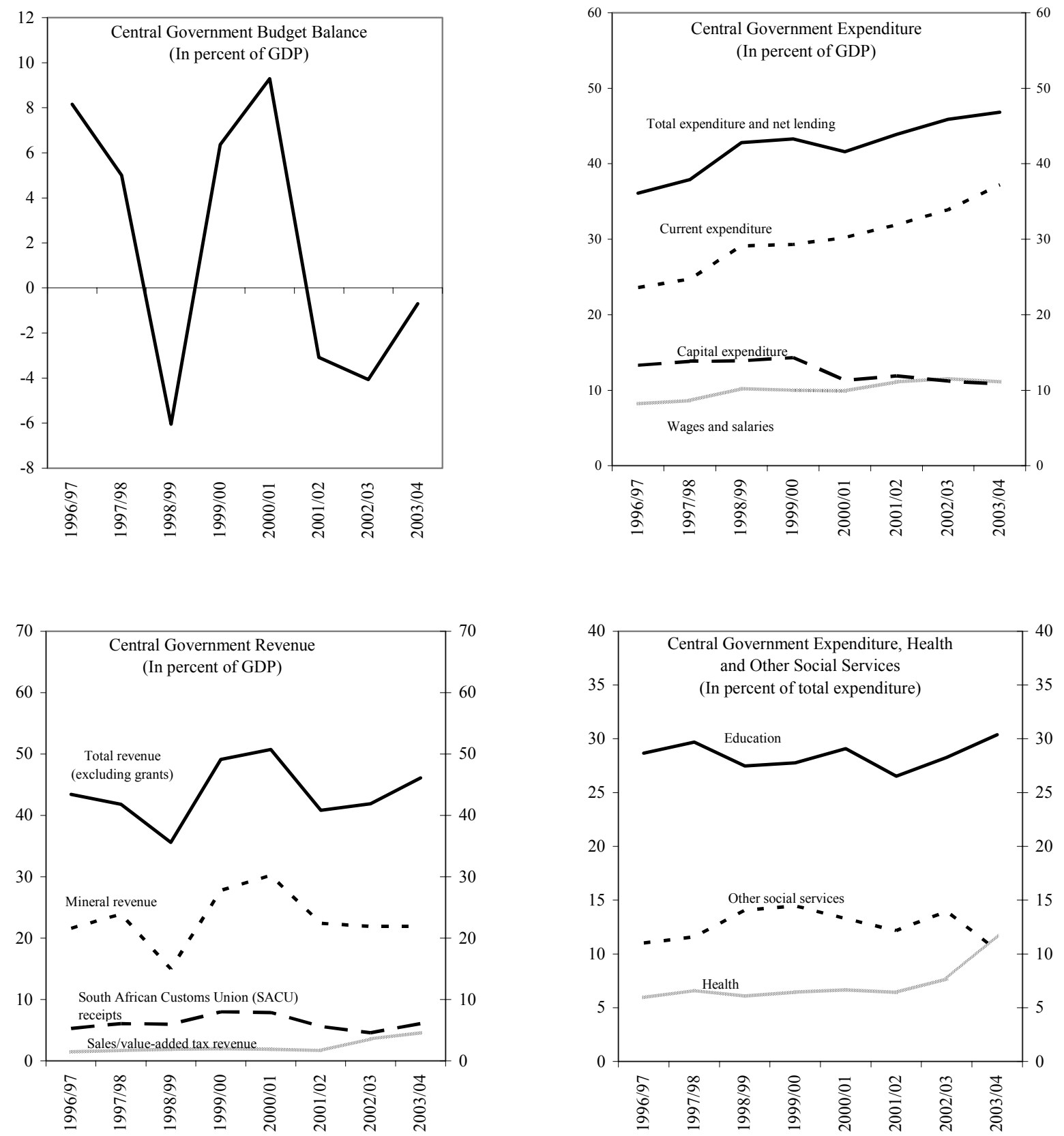

1/Fiscal year begins April 1. 
Figure 4. Botswana: Selected Exchange Rate Indicators, January 1995 - December 2003 $(1995=100 ;$ foreign currency per pula $) 1 /$
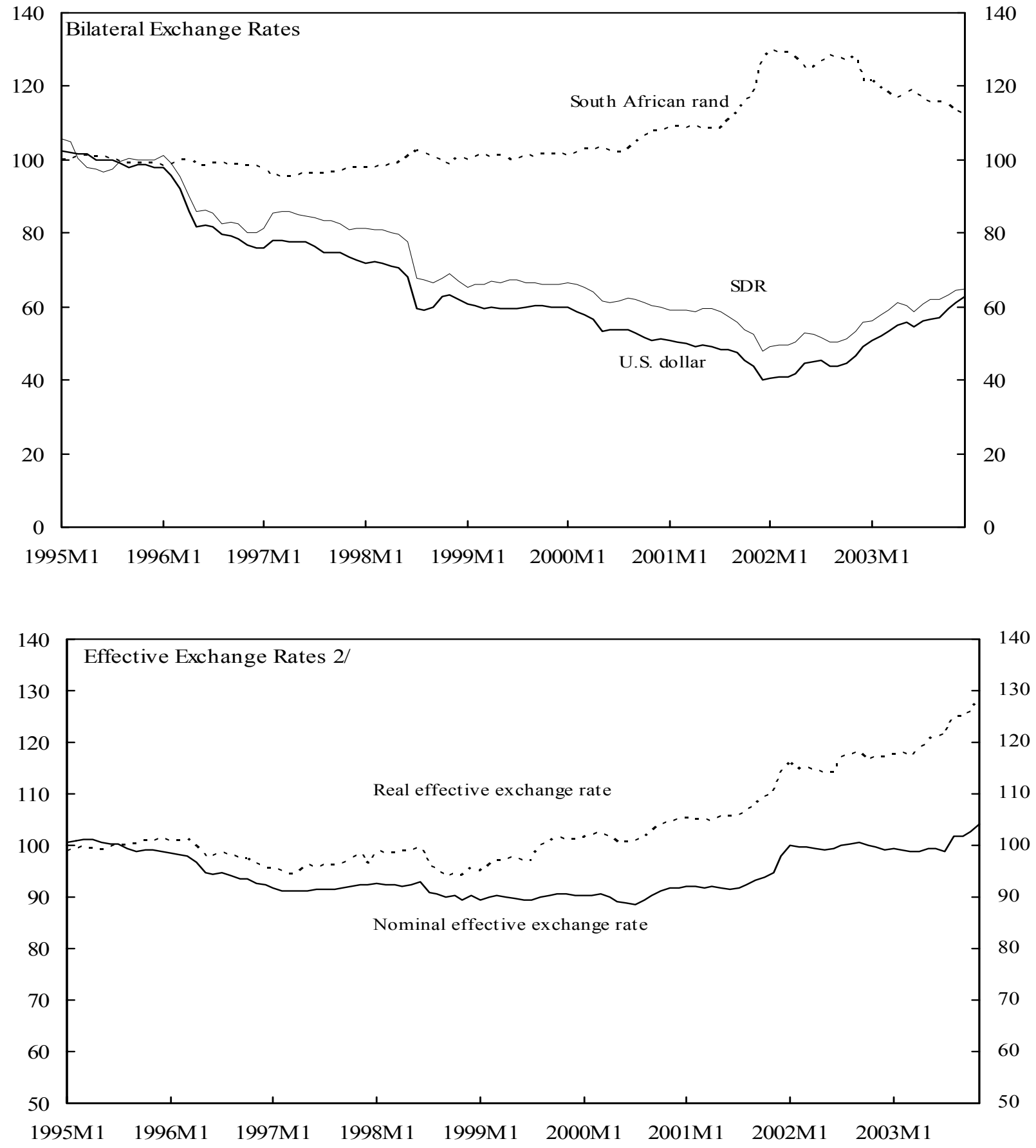

Source: Fund staff estimates.

$1 /$ A rise in the index indicates an appreciation of the pula.

2/ Differ from the authorities' estimates, which are based on the undisclosed currency basket weights. 
Table 1. Botswana: Selected Economic and Financial Indicators, 1999-2004

\begin{tabular}{|c|c|c|c|c|c|c|}
\hline & 1999 & 2000 & 2001 & $\begin{array}{r}2002 \\
\text { Est. } \\
\end{array}$ & $\begin{array}{r}2003 \\
\text { Est. } \\
\end{array}$ & $\begin{array}{l}2004 \\
\text { Proj. }\end{array}$ \\
\hline & \multicolumn{6}{|c|}{ (Annual percentage change, unless otherwise indicated) } \\
\hline \multicolumn{7}{|l|}{ National income and prices } \\
\hline Real GDP 1/ & 6.6 & 8.4 & 2.3 & 5.5 & 5.4 & 3.8 \\
\hline Consumer prices (average) & 7.8 & 8.5 & 6.6 & 8.0 & 9.3 & 6.5 \\
\hline Consumer prices (end of period) & 8.4 & 8.5 & 5.7 & 11.2 & 6.4 & 6.7 \\
\hline Nominal GDP (in billions of pula) 1 / & 24.9 & 28.7 & 32.0 & 34.9 & 38.2 & 41.5 \\
\hline \multicolumn{7}{|l|}{ External sector } \\
\hline Exports of goods, f.o.b. (in U.S. dollar terms) 2/ & 28.4 & 0.8 & -13.3 & 2.1 & 27.9 & 4.0 \\
\hline Of which: diamonds & 43.4 & 5.4 & -13.4 & 2.1 & 25.5 & 2.0 \\
\hline Imports of goods, f.o.b. (in U.S. dollar terms) 2/ & -6.0 & -5.2 & -9.3 & 0.0 & 26.5 & 16.3 \\
\hline Nominal effective exchange rate (depreciation -) 3/ & 0.1 & 1.5 & 6.9 & 1.2 & 0.4 & $\ldots$ \\
\hline Real effective exchange rate (depreciation -) 3/ & 5.9 & 3.7 & 8.8 & 2.4 & 4.0 & $\ldots$ \\
\hline Nominal exchange rate (pula per U.S. dollar), average & 4.6 & 5.1 & 5.9 & 6.3 & 4.9 & $\ldots$ \\
\hline \multicolumn{7}{|l|}{ Central government finance 4 / } \\
\hline Total revenue and grants & 55.8 & 18.0 & -10.0 & 12.6 & 19.5 & 13.4 \\
\hline Of which: mineral revenue & 109.9 & 25.1 & -16.4 & 7.2 & 8.5 & 6.8 \\
\hline Southern African Customs Union receipts & 53.1 & 13.3 & -20.9 & -9.4 & 43.8 & 36.8 \\
\hline \multirow[t]{2}{*}{ Total expenditure and net lending } & 16.4 & 10.6 & 18.5 & 14.9 & 11.0 & 8.4 \\
\hline & \multicolumn{6}{|c|}{ (Twelve-month percentage change, unless otherwise indicated) } \\
\hline \multicolumn{7}{|l|}{ Money and banking 5/ } \\
\hline Net foreign assets & 8.3 & 16.8 & 22.7 & -27.5 & -14.1 & 0.1 \\
\hline Net domestic credit & 1.0 & -20.3 & -16.2 & 55.8 & 52.6 & 6.0 \\
\hline Net claims on government 6/ & -5.5 & -19.8 & -15.1 & 40.6 & 40.5 & 7.3 \\
\hline Claims on private sector & 35.5 & 22.5 & 11.4 & 23.7 & 15.0 & 3.0 \\
\hline Other items (net) & -16.3 & -25.0 & -29.9 & -6.6 & 8.2 & 9.1 \\
\hline Money and quasi money (M2) 7/ & 26.3 & 1.4 & 31.2 & -1.1 & 11.3 & 9.0 \\
\hline \multirow[t]{2}{*}{ Velocity (GDP relative to M2) } & 3.6 & 3.7 & 3.6 & 3.4 & 3.6 & 3.6 \\
\hline & \multicolumn{6}{|c|}{ (In percent) } \\
\hline \multicolumn{7}{|l|}{ Interest and credit } \\
\hline Bank of Botswana lending rate & 13.3 & 14.3 & 14.3 & 15.3 & 14.3 & $\ldots$ \\
\hline \multicolumn{7}{|l|}{ Commercial banks } \\
\hline Prime lending rate & 14.8 & 15.8 & 15.8 & 16.7 & 16.7 & $\ldots$ \\
\hline \multirow[t]{2}{*}{ Deposit rate } & 9.7 & 10.2 & 10.2 & 10.2 & 10.6 & $\ldots$ \\
\hline & \multicolumn{6}{|c|}{ (In percent of GDP, unless otherwise indicated) } \\
\hline \multicolumn{7}{|l|}{ Investment and savings $1 /$} \\
\hline Gross investment & 19.9 & 19.0 & 24.7 & 24.5 & 25.5 & 26.6 \\
\hline Public & 11.8 & 11.8 & 11.7 & 11.1 & 11.2 & 13.1 \\
\hline Private & 8.2 & 7.2 & 13.0 & 13.4 & 14.3 & 13.5 \\
\hline Gross national savings & 31.2 & 29.9 & 36.2 & 35.8 & 34.1 & 32.6 \\
\hline Public & 5.8 & 6.0 & 9.5 & 7.8 & 7.9 & 10.4 \\
\hline Private & 25.4 & 23.9 & 26.7 & 28.0 & 26.2 & 22.2 \\
\hline \multicolumn{7}{|l|}{ Central government finance 4 / } \\
\hline Total revenue and grants & 49.7 & 50.9 & 40.8 & 41.9 & 46.1 & 48.9 \\
\hline Total expenditure and net lending & 43.3 & 41.6 & 43.9 & 45.9 & 46.8 & 50.0 \\
\hline Current expenditure & 29.3 & 30.2 & 31.9 & 33.9 & 37.2 & 38.5 \\
\hline Capital expenditure & 14.3 & 11.3 & 11.9 & 11.2 & 10.8 & 12.8 \\
\hline Overall balance (including grants) & 6.4 & 9.3 & -3.1 & -4.1 & -0.7 & -1.1 \\
\hline Domestic financing & -6.2 & -8.7 & 3.8 & 4.7 & 1.5 & 1.5 \\
\hline Foreign financing & -0.1 & -0.6 & -0.6 & -0.7 & -0.7 & -0.3 \\
\hline \multicolumn{7}{|l|}{ External sector } \\
\hline External current account balance (deficit -) & 12.3 & 10.4 & 11.5 & 11.6 & 11.0 & 6.4 \\
\hline External debt 8/ & 10.4 & 9.0 & 8.0 & 8.7 & 7.8 & 7.1 \\
\hline \multirow[t]{2}{*}{ Total public debt (in percent of total exports) } & 20.9 & 19.4 & 19.4 & 20.3 & 20.3 & 21.5 \\
\hline & & (In bi & f U.S. C & , unless & wise in & \\
\hline Change in reserves (increase -) & -0.3 & -0.1 & 0.4 & 0.4 & 0.2 & -0.5 \\
\hline Gross official reserves (end of period) & 6.2 & 6.3 & 5.9 & 5.5 & 5.3 & 5.8 \\
\hline (in months of imports of goods and services) & 31.1 & 32.5 & 33.2 & 30.8 & 23.2 & 20.9 \\
\hline
\end{tabular}

Sources: Botswana authorities; and Fund staff estimates and projections.

1/ For national accounts, year begins July 1. Balance of Payments and monetary data follow calendar year, and fiscal year begins on April 1.

2/ Calendar year.

3/ End of period.

4/ Fiscal year begins April 1.

5/ For 2003, as of end-October.

6/ From 2002 onwards, figures include the government transfer of deposits to private pension fund managers as a result of

privatization of the civil servants' pension scheme.

7/ The decline in 2002 reflects largely the fall in quasi money as a result of shift of asset portfolios from time deposits to Bank of Botswana certificates.

8/ Medium- and long-term public and publicly guaranteed debt outstanding. 
Table 2. Botswana: Sectoral GDP and Savings-Investment Balances, 1996/97-2003/04

\begin{tabular}{|c|c|c|c|c|c|c|c|c|}
\hline & $1996 / 97$ & 1997/98 & 1998/99 & $1999 / 2000$ & $2000 / 01$ & $2001 / 02$ & $\begin{array}{c}\text { 2002/03 } \\
\text { Prel. } \\
\end{array}$ & $\begin{array}{c}\text { 2003/04 } \\
\text { Proj. }\end{array}$ \\
\hline & \multicolumn{8}{|c|}{ (In millions of pula) } \\
\hline Consumption & $10,025.7$ & $11,589.1$ & $13,515.8$ & $15,365.7$ & $17,180.4$ & $19,860.2$ & $19,115.7$ & $24,010.4$ \\
\hline Public & $4,711.0$ & $5,452.9$ & $6,578.8$ & $7,524.5$ & $8,741.9$ & $10,552.6$ & $12,136.2$ & $14,264.8$ \\
\hline Private & $5,314.7$ & $6,136.1$ & $6,936.9$ & $7,841.2$ & $8,438.5$ & $9,307.6$ & $6,979.5$ & $9,745.6$ \\
\hline Gross investment & $4,603.9$ & $6,056.1$ & $7,917.2$ & $4,968.2$ & $5,436.4$ & $7,896.0$ & $8,546.1$ & $9,752.8$ \\
\hline Public & $2,239.6$ & $2,695.5$ & $3,333.2$ & $2,934.5$ & $3,371.9$ & $3,729.3$ & $3,867.5$ & $4,298.5$ \\
\hline Private (including changes in stock) & $2,364.3$ & $3,360.5$ & $4,583.9$ & $2,033.7$ & $2,064.5$ & $4,166.7$ & $4,678.6$ & $5,454.3$ \\
\hline Net exports of goods and services & $1,891.0$ & $2,427.4$ & -660.4 & $2,907.6$ & $3,466.7$ & $3,139.2$ & $8,548.9$ & $3,773.7$ \\
\hline Exports of goods and services & $7,913.3$ & $11,061.9$ & $9,978.1$ & $13,998.8$ & $15,306.5$ & $15,602.5$ & $17,160.4$ & $17,235.7$ \\
\hline Imports of goods and services & $-6,022.3$ & $-8,634.5$ & $-10,638.5$ & $-11,091.2$ & $-11,839.8$ & $-12,463.3$ & $-8,611.6$ & $-13,461.9$ \\
\hline Gross domestic savings & $6,742.4$ & $7,802.9$ & $9,776.7$ & $7,788.8$ & $8,573.3$ & $11,586.7$ & $12,494.4$ & $13,041.1$ \\
\hline Public & 770.6 & $1,451.8$ & $1,806.9$ & $1,452.8$ & $1,719.1$ & $3,045.8$ & $2,711.7$ & $3,014.0$ \\
\hline Private & $5,971.9$ & $6,351.1$ & $7,969.8$ & $6,336.0$ & $6,854.2$ & $8,540.9$ & $9,782.7$ & $10,027.1$ \\
\hline \multirow[t]{2}{*}{ GDP at market prices } & $17,740.2$ & $20,162.6$ & $21,523.7$ & $24,942.9$ & $28,671.4$ & $32,000.1$ & $34,926.7$ & $38,210.2$ \\
\hline & \multicolumn{8}{|c|}{ (In percent of GDP) } \\
\hline Consumption & 56.5 & 57.5 & 62.8 & 61.6 & 59.9 & 62.1 & 54.7 & 62.8 \\
\hline Public & 26.6 & 27.0 & 30.6 & 30.2 & 30.5 & 33.0 & 34.7 & 37.3 \\
\hline Private & 30.0 & 30.4 & 32.2 & 31.4 & 29.4 & 29.1 & 20.0 & 25.5 \\
\hline Gross investment & 26.0 & 30.0 & 36.8 & 19.9 & 19.0 & 24.7 & 24.5 & 25.5 \\
\hline Public & 12.6 & 13.4 & 15.5 & 11.8 & 11.8 & 11.7 & 11.1 & 11.2 \\
\hline Private (including changes in stock) & 13.3 & 16.7 & 21.3 & 8.2 & 7.2 & 13.0 & 13.4 & 14.3 \\
\hline Net exports of goods and services & 10.7 & 12.0 & -3.1 & 11.7 & 12.1 & 9.8 & 24.5 & 9.9 \\
\hline Exports of goods and services & 44.6 & 54.9 & 46.4 & 56.1 & 53.4 & 48.8 & 49.1 & 45.1 \\
\hline Imports of goods and services & -33.9 & -42.8 & -49.4 & -44.5 & -41.3 & -38.9 & -24.7 & -35.2 \\
\hline Gross domestic savings & 38.0 & 38.7 & 45.4 & 31.2 & 29.9 & 36.2 & 35.8 & 34.1 \\
\hline Public & 4.3 & 7.2 & 8.4 & 5.8 & 6.0 & 9.5 & 7.8 & 7.9 \\
\hline \multirow[t]{2}{*}{ Private } & 33.7 & 31.5 & 37.0 & 25.4 & 23.9 & 26.7 & 28.0 & 26.2 \\
\hline & \multicolumn{8}{|c|}{ (Annual change in percent) } \\
\hline Real GDP & 5.6 & 8.1 & 4.1 & 6.6 & 8.4 & 2.3 & 5.5 & 5.4 \\
\hline Of which: private nonmining real GDP & 4.7 & 6.7 & 8.3 & 3.4 & 3.1 & 4.5 & 5.6 & 5.2 \\
\hline Agriculture & -7.5 & 5.9 & -7.6 & -8.7 & 7.3 & -2.5 & 1.5 & 1.5 \\
\hline Mining & 5.8 & 9.5 & -2.8 & 12.1 & 17.2 & -3.1 & 6.0 & 6.3 \\
\hline Manufacturing & 3.7 & 5.4 & 5.7 & 3.5 & -0.4 & 0.2 & 4.0 & 4.0 \\
\hline Water and electricity & 4.6 & 9.9 & 12.9 & 11.3 & 5.4 & 3.7 & 6.0 & 5.5 \\
\hline Construction & 5.5 & 4.3 & 11.5 & 2.4 & 1.6 & 4.7 & 5.0 & 4.7 \\
\hline Trade and hotels & 13.9 & 4.7 & 5.6 & 6.2 & 6.5 & 8.2 & 7.0 & 6.5 \\
\hline Transport & 4.3 & 9.1 & 16.2 & 2.6 & 5.0 & 7.0 & 5.0 & 5.0 \\
\hline Finance and business services & 1.2 & 9.7 & 9.0 & 4.3 & 5.1 & 7.1 & 6.5 & 5.0 \\
\hline General government & 8.3 & 9.3 & 6.3 & 6.0 & 6.7 & 8.3 & 4.0 & 4.0 \\
\hline Consumer prices (annual average) $1 /$ & 10.1 & 8.9 & 6.5 & 7.8 & 8.5 & 6.6 & 8.0 & 9.3 \\
\hline
\end{tabular}

Sources: Botswana authorities; and Fund staff estimates and projections.

1/ Calendar year. 
Table 3: Botswana: Central Government Operations, 1998/99-2003/04 1/

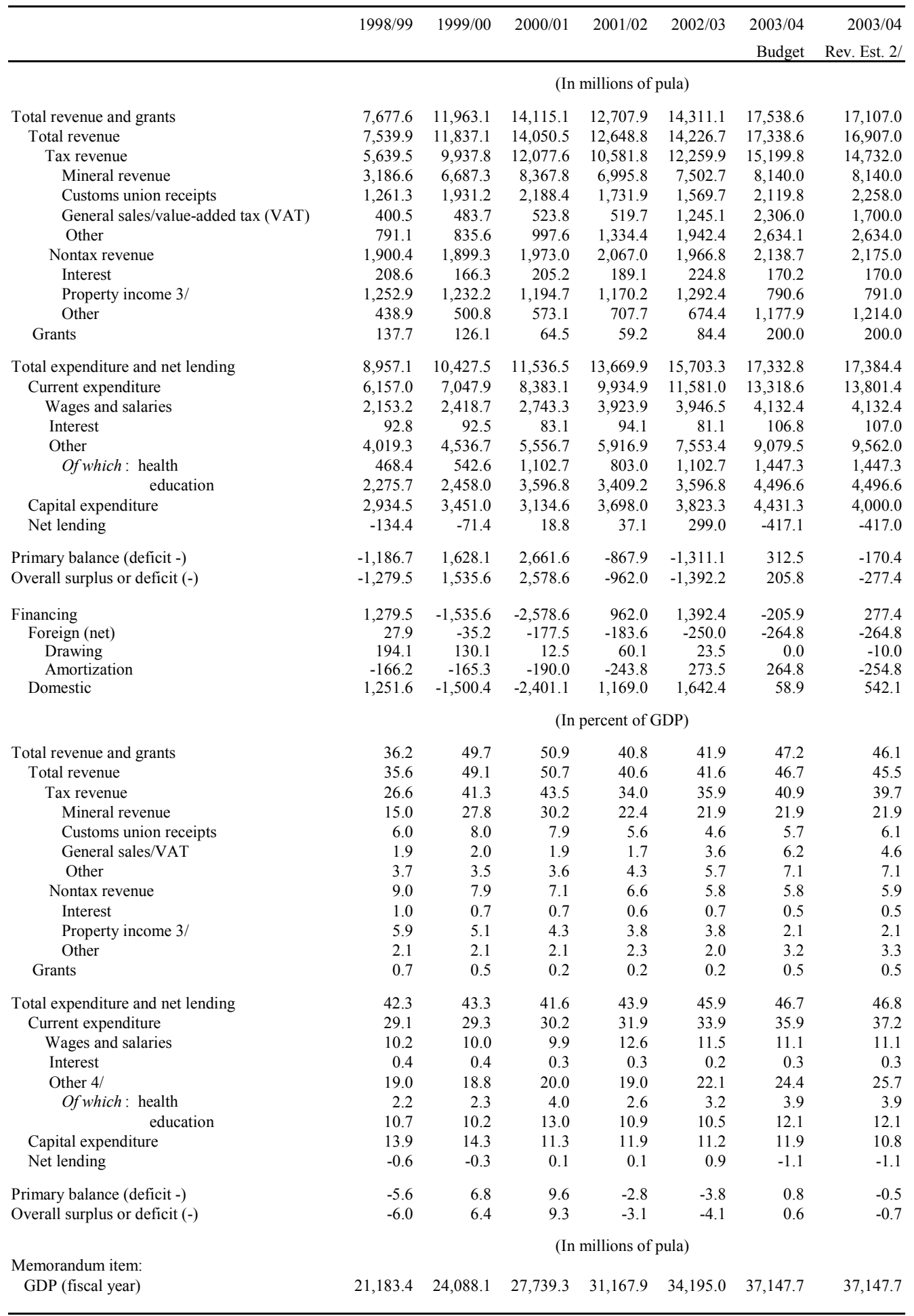

Sources: Ministry of Finance and Development Planning; and Fund staff estimates and projections.

1/ Fiscal year begins on April 1

$2 /$ Authorities' and staff estimates and projections.

3/ Original budget estimates adjusted for supplementary expenditure and revised outlook for VAT revenue.

4/ Expenditure on goods and services, and transfers. 
Table 4. Botswana: Monetary Survey, 1996-2003 1/

\begin{tabular}{|c|c|c|c|c|c|c|c|c|}
\hline & 1996 & 1997 & 1998 & 1999 & 2000 & 2001 & 2002 & 2003 \\
\hline & \multicolumn{8}{|c|}{ (In millions of pula; end of period) } \\
\hline Net foreign assets & $18,657.7$ & $22,321.2$ & $27,747.3$ & $30,051.3$ & $35,110.5$ & $43,074.8$ & $31,247.3$ & $26,829.0$ \\
\hline Bank of Botswana & $18,355.6$ & $21,636.5$ & $26,502.4$ & $28,866.8$ & $33,900.4$ & $41,211.5$ & $29,984.1$ & $25,779.5$ \\
\hline Assets & $18,355.6$ & $21,636.5$ & $26,502.4$ & $28,866.8$ & $33,900.4$ & $41,211.5$ & $29,984.1$ & $25,779.5$ \\
\hline Liabilities & 0.0 & 0.0 & 0.0 & 0.0 & 0.0 & 0.0 & 0.0 & 0.0 \\
\hline Commercial banks & 302.1 & 684.6 & $1,245.0$ & $1,184.5$ & $1,210.1$ & $1,863.3$ & $1,263.2$ & $1,049.5$ \\
\hline Assets & 453.8 & 805.1 & $1,416.5$ & $1,345.6$ & $1,434.9$ & $2,230.9$ & $1,554.8$ & $1,625.3$ \\
\hline Liabilities & -151.7 & -120.4 & -171.6 & -161.1 & -224.8 & -367.7 & -291.6 & -575.8 \\
\hline Net domestic assets & $-15,467.9$ & $-18,217.6$ & $-22,025.8$ & $-22,823.1$ & $-27,782.0$ & $-33,458.1$ & $-21,739.7$ & $-16,121.1$ \\
\hline Net domestic credit & $-5,463.5$ & $-13,498.5$ & $-16,128.3$ & $-15,961.6$ & $-19,204.6$ & $-22,319.8$ & $-9,869.5$ & $-4,681.2$ \\
\hline Net claims on the government & $-7,259.4$ & $-15,395.9$ & $-19,086.6$ & $-20,137.5$ & $-24,130.3$ & $-27,778.5$ & $-16,490.6$ & $-11,759.9$ \\
\hline Bank of Botswana & $-7,220.6$ & $-15,362.3$ & $-19,071.6$ & $-20,086.1$ & $-24,026.2$ & $-27,718.6$ & $-16,433.0$ & $-11,547.7$ \\
\hline Commercial banks & -38.9 & -33.6 & -15.0 & -51.4 & -104.2 & -59.8 & -57.6 & -212.2 \\
\hline Claims on nongovernment & $1,796.0$ & $1,897.3$ & $2,958.3$ & $4,175.9$ & $4,925.7$ & $5,458.6$ & $6,621.1$ & $7,078.7$ \\
\hline Claims on parastatals & 70.5 & 61.4 & 266.7 & 527.6 & 458.1 & 479.9 & 462.0 & 479.2 \\
\hline Claims on the private sector & $1,725.5$ & $1,835.9$ & $2,691.6$ & $3,648.2$ & $4,467.7$ & $4,978.8$ & $6,159.1$ & $6,599.5$ \\
\hline Of which : households & 849.5 & 943.0 & $1,389.5$ & $1,995.0$ & $2,429.6$ & $2,947.9$ & $3,560.8$ & $3,750.0$ \\
\hline private enterprises & 776.5 & 832.1 & $1,071.4$ & $1,523.4$ & $1,914.8$ & $1,966.7$ & $2,594.6$ & $2,849.5$ \\
\hline Other items (net) & $-10,004.4$ & $-4,719.1$ & $-5,897.5$ & $-6,861.5$ & $-8,577.4$ & $-11,138.2$ & $-11,870.2$ & $-11,439.9$ \\
\hline Money plus quasi money (M2) & $3,189.9$ & $4,103.5$ & $5,721.6$ & $7,228.2$ & $7,328.5$ & $9,616.7$ & $9,507.6$ & $10,707.9$ \\
\hline Money & 950.9 & $1,037.8$ & $1,513.0$ & $1,774.6$ & $1,896.6$ & $2,350.7$ & $2,524.0$ & $2,800.9$ \\
\hline Currency & 247.1 & 275.7 & 352.7 & 403.7 & 427.0 & 481.4 & 469.7 & 599.8 \\
\hline Current deposits & 703.8 & 762.1 & $1,160.3$ & $1,370.9$ & $1,469.6$ & $1,869.3$ & $2,054.3$ & $2,201.1$ \\
\hline Quasi money & $2,239.0$ & $3,065.7$ & $4,208.6$ & $5,453.7$ & $5,431.9$ & $7,266.0$ & $6,983.6$ & $7,907.0$ \\
\hline \multicolumn{9}{|l|}{ Memorandum items: } \\
\hline Broad money (M3) & 6,006 & 7,412 & 8,968 & 11,458 & 11,041 & 14,764 & 17,171 & 20,902 \\
\hline \multicolumn{9}{|l|}{ Of which } \\
\hline Bank of Botswana certificates (BoBCs) 2/ & $2,815.7$ & $3,308.2$ & $1,976.8$ & $4,230.2$ & $3,712.4$ & $5,147.7$ & $7,663.5$ & $10,194.2$ \\
\hline \multicolumn{9}{|c|}{ (Twelve-month percentage change) } \\
\hline Net foreign assets & 52.8 & 19.6 & 24.3 & 8.3 & 16.8 & 22.7 & -27.5 & -14.1 \\
\hline Net domestic assets & -62.4 & -17.8 & -20.9 & -3.6 & -21.7 & -20.4 & 35.0 & 25.8 \\
\hline Net domestic credit & -16.0 & -147.1 & -19.5 & 1.0 & -20.3 & -16.2 & 55.8 & 52.6 \\
\hline Net claims on the government & -11.9 & -112.1 & -24.0 & -5.5 & -19.8 & -15.1 & 40.6 & 28.7 \\
\hline Claims on nongovernment & 1.1 & 5.6 & 55.9 & 41.2 & 18.0 & 10.8 & 21.3 & 6.9 \\
\hline Claims on parastatals & -25.6 & -12.8 & 334.2 & 97.8 & -13.2 & 4.8 & -3.7 & 3.7 \\
\hline Claims on the private sector & 2.6 & 6.4 & 46.6 & 35.5 & 22.5 & 11.4 & 23.7 & 7.2 \\
\hline Of which : households & 8.7 & 11.0 & 47.3 & 43.6 & 21.8 & 21.3 & 20.8 & 5.3 \\
\hline private enterprises & -0.2 & 7.2 & 28.8 & 42.2 & 25.7 & 2.7 & 31.9 & 9.8 \\
\hline Other items (net) & -107.6 & 52.8 & -25.0 & -16.3 & -25.0 & -29.9 & -6.6 & 3.6 \\
\hline Money plus quasi money (M2) 3/ & 18.8 & 28.6 & 39.4 & 26.3 & 1.4 & 31.2 & -1.1 & 12.6 \\
\hline Broad money (M3) & 29.2 & 23.4 & 21.0 & 27.8 & -3.6 & 33.7 & 16.3 & 21.7 \\
\hline \multicolumn{9}{|c|}{ (Annual change in percent of beginning-of-year money stock, unless otherwise indicated) } \\
\hline Net foreign assets & 240.0 & 114.8 & 132.2 & 40.3 & 70.0 & 108.7 & -123.0 & -46.5 \\
\hline Net domestic assets & -221.2 & -86.2 & -92.8 & -13.9 & -68.6 & -77.5 & 121.9 & 59.1 \\
\hline Net domestic credit & -28.1 & -251.9 & -64.1 & 2.9 & -44.9 & -42.5 & 129.5 & 54.6 \\
\hline Net claims on the government 4/ & -28.8 & -255.1 & -89.9 & -18.4 & -55.2 & -49.8 & 117.4 & 49.8 \\
\hline Claims on nongovernment & 0.7 & 3.2 & 25.9 & 21.3 & 10.4 & 7.3 & 12.1 & 4.8 \\
\hline Claims on parastatals & -0.9 & -0.3 & 5.0 & 4.6 & -1.0 & 0.3 & -0.2 & 0.2 \\
\hline Claims on the private sector & 1.6 & 3.5 & 20.9 & 16.7 & 11.3 & 7.0 & 12.3 & 4.6 \\
\hline Of which : households & 2.5 & 2.9 & 10.9 & 10.6 & 6.0 & 7.1 & 6.4 & 2.0 \\
\hline private enterprises & -0.1 & 1.7 & 5.8 & 7.9 & 5.4 & 0.7 & 6.5 & 2.7 \\
\hline Other items (net) & -193.1 & 165.7 & -28.7 & -16.8 & -23.7 & -34.9 & -7.6 & 4.5 \\
\hline Broad money (M4) & 53.4 & 49.9 & 49.1 & 46.3 & -4.5 & 61.6 & 20.4 & 37.4 \\
\hline \multicolumn{9}{|l|}{ Memorandum items: } \\
\hline Nominal GDP (calendar year, in millions of pula) & $15,972.0$ & $18,951.4$ & $20,843.1$ & $23,233.3$ & $26,807.1$ & $30,335.8$ & $33,463.4$ & $36,568.5$ \\
\hline Growth of nominal GDP (annual change in percent) & 20.7 & 18.7 & 10.0 & 11.5 & 15.4 & 13.2 & 10.3 & 10.3 \\
\hline Velocity (GDP rel. to broad money, M2) & 5.4 & 5.2 & 4.2 & 3.6 & 3.7 & 3.6 & 3.5 & 3.4 \\
\hline
\end{tabular}

Sources: Bank of Botswana; and Fund staff estimates.

1/ End of period. For 2003, end-October.

2/ Bank of Botswana Certificates (BoBCs) held by banks and nonbank financial institutions.

3/ The decline in 2002 reflects largely the fall in quasi money as a result of shift of asset portfolios from time deposits to BoBCs.

4/ From 2002 onward, figures include the government transfer of deposits to private pension fund managers as a result

of the privatization of the civil servants' pension scheme. 
Table 5. Botswana: Assets and Liabilities of the Bank of Botswana, 1996-2003

(In millions of pula; end of period)

\begin{tabular}{|c|c|c|c|c|c|c|c|c|}
\hline & 1996 & 1997 & 1998 & 1999 & 2000 & 2001 & 2002 & $20031 /$ \\
\hline Assets & $18,437.9$ & $21,730.4$ & $26,611.9$ & $28,990.7$ & $34,033.9$ & $41,340.9$ & $30,108.6$ & $25,531.8$ \\
\hline Foreign assets & $18,355.6$ & $21,636.5$ & $26,502.4$ & $28,866.8$ & $33,900.4$ & $41,211.5$ & $29,984.1$ & $25,403.7$ \\
\hline Pula Fund & $5,394.2$ & $17,654.1$ & $23,561.9$ & $24,453.7$ & $28,711.6$ & $32,175.9$ & $25,523.5$ & $19,714.7$ \\
\hline Liquidity portfolio & $12,689.6$ & $3,721.3$ & $2,545.2$ & $4,074.9$ & $4,833.4$ & $8,533.8$ & $3,985.5$ & $5,090.5$ \\
\hline Matched assets/liability portfolio & 17.1 & 11.9 & 18.5 & 16.3 & 22.6 & 29.6 & 55.6 & 163.2 \\
\hline Fund accounts & 254.8 & 249.2 & 376.7 & 321.9 & 332.7 & 472.2 & 417.4 & 435.3 \\
\hline Holding of SDRs & 150.4 & 156.1 & 203.4 & 178.3 & 208.8 & 276.7 & 242.5 & 225.8 \\
\hline Reserve position & 97.3 & 90.3 & 173.0 & 143.6 & 124.0 & 194.9 & 175.5 & 209.5 \\
\hline Valuation adjustment & 7.0 & 2.8 & 0.3 & 0.0 & 0.0 & 0.6 & 1.4 & $\ldots$ \\
\hline Domestic assets & 82.3 & 93.9 & 109.5 & 123.8 & 133.5 & 129.4 & 124.6 & 128.1 \\
\hline Loans and advances to financial institutions & 0.0 & 0.0 & 0.0 & 0.0 & 0.0 & 0.0 & 0.0 & ... \\
\hline Fixed assets & 98.5 & 100.0 & 108.0 & 122.0 & 131.1 & 129.3 & 126.6 & 128.1 \\
\hline Other assets & -16.2 & -6.1 & 1.5 & 1.8 & 2.4 & 0.1 & -2.1 & $\ldots$ \\
\hline Liabilities & $18,437.9$ & $21,730.4$ & $26,611.9$ & $28,990.7$ & $34,033.9$ & $41,340.9$ & $30,108.6$ & $25,531.8$ \\
\hline Reserve money & 453.4 & 572.0 & 707.3 & 807.9 & 857.3 & 969.5 & $1,049.7$ & $1,143.7$ \\
\hline Currency in circulation & 355.9 & 417.1 & 497.7 & 606.8 & 606.5 & 701.1 & 759.1 & 787.6 \\
\hline Currency outside banks & 247.1 & 275.7 & 352.7 & 403.7 & 427.0 & 481.4 & 469.7 & 611.1 \\
\hline Pula currency in banks & 108.8 & 141.4 & 145.0 & 203.2 & 179.5 & 219.7 & 289.4 & 176.5 \\
\hline Bankers' deposits & 97.5 & 155.0 & 209.6 & 201.1 & 250.8 & 268.4 & 290.6 & 356.1 \\
\hline Private sector time deposits & 46.7 & 62.7 & 25.7 & 171.9 & 183.4 & 183.8 & 285.9 & 302.9 \\
\hline Bank of Botswana certificates outstanding & $2,815.7$ & $3,308.2$ & $3,246.2$ & $4,230.2$ & $3,712.4$ & $5,147.7$ & $7,663.5$ & $10,521.2$ \\
\hline Bankers & $1,847.1$ & $2,424.2$ & $2,257.8$ & $2,809.0$ & $2,483.8$ & $3,845.2$ & $5,611.7$ & $7,316.3$ \\
\hline Others & 968.6 & 883.9 & 988.4 & $1,421.2$ & $1,228.6$ & $1,302.5$ & $2,424.8$ & $3,204.9$ \\
\hline Government deposits & $7,220.6$ & $15,362.3$ & $19,071.6$ & $20,086.1$ & $24,026.2$ & $27,718.6$ & $16,433.0$ & $10,655.4$ \\
\hline Capital and reserves & $6,085.5$ & $1,866.0$ & $3,201.6$ & $3,387.3$ & $4,353.7$ & $6,629.7$ & $4,074.8$ & $2,637.6$ \\
\hline Paid-up capital & 3.6 & 25.0 & 25.0 & 25.0 & 25.0 & 25.0 & 25.0 & 25.0 \\
\hline General reserve & $5,754.6$ & $1,600.0$ & $1,600.0$ & $1,600.0$ & $1,600.0$ & $1,600.0$ & $1,600.0$ & $1,600.0$ \\
\hline Revaluation reserve & 327.4 & 241.0 & $1,576.6$ & $1,762.3$ & $2,728.7$ & $5,004.7$ & $2,449.8$ & $1,012.6$ \\
\hline Other liabilities & $1,816.2$ & 559.3 & 359.4 & 307.4 & 901.0 & 691.6 & 601.6 & 271.0 \\
\hline
\end{tabular}

1/ For 2003, data as of end-October. 
Table 6. Botswana: Balance of Payments, 1997-2003 1/

(In millions of U.S. dollars, unless otherwise indicated)

\begin{tabular}{|c|c|c|c|c|c|c|c|}
\hline & 1997 & 1998 & 1999 & 2000 & 2001 & $\begin{array}{l}2002 \\
\text { Prel. }\end{array}$ & $\begin{array}{r}2003 \\
\text { Rev.Est. }\end{array}$ \\
\hline Current account balance & 722.0 & 204.7 & 619.0 & 546.7 & 600.7 & 616.7 & 812.7 \\
\hline Trade balance & 896.1 & 78.0 & 785.6 & 904.5 & 713.8 & 763.3 & 997.7 \\
\hline $\begin{array}{l}\text { Exports, f.o.b. } \\
\text { Of which }\end{array}$ & $2,822.1$ & $2,072.8$ & $2,661.3$ & $2,682.1$ & $2,325.7$ & $2,375.5$ & $3,037.8$ \\
\hline Diamonds & $2,104.1$ & $1,479.8$ & $2,121.8$ & $2,235.7$ & $1,937.1$ & $1,977.6$ & $2,482.4$ \\
\hline Imports, f.o.b & $-1,926.0$ & $-1,994.8$ & $-1,875.7$ & $-1,777.7$ & $-1,611.9$ & $-1,612.2$ & $-2,040.1$ \\
\hline \multicolumn{8}{|l|}{ Of which } \\
\hline Food, beverages, and tobacco & -296.9 & -296.9 & -305.6 & -293.6 & -253.9 & -316.1 & -333.8 \\
\hline Chemical and rubber products & -205.4 & -200.7 & -203.6 & -203.0 & -187.5 & -216.1 & -246.5 \\
\hline Metal and metal products & -241.4 & -228.0 & -189.9 & -151.1 & -140.0 & -136.7 & -184.1 \\
\hline Machinery and electrical equipment & -398.4 & -480.5 & -463.7 & -463.0 & -357.5 & -380.0 & -470.0 \\
\hline Services & -230.7 & -235.2 & -156.1 & -223.2 & -173.7 & -188.7 & -232.3 \\
\hline Transportation & -175.0 & -164.9 & -162.4 & -174.4 & -154.8 & -153.7 & -193.8 \\
\hline Travel & 43.2 & 72.2 & 87.4 & 24.5 & 26.0 & 17.6 & 29.6 \\
\hline Other services & -98.9 & -142.6 & -81.1 & -73.4 & -44.9 & -52.6 & -68.1 \\
\hline Income & -144.9 & 120.3 & -262.6 & -352.2 & -137.8 & -276.0 & -340.2 \\
\hline Compensation of employees & -10.5 & -15.0 & -26.4 & -36.8 & -36.8 & -38.6 & -58.5 \\
\hline \multicolumn{8}{|l|}{ Of which } \\
\hline Earnings on reserves & 545.4 & 531.3 & 348.0 & 281.8 & 285.0 & 266.3 & 247.6 \\
\hline Dividends and profits & -572.7 & -313.2 & -575.7 & -587.2 & -384.6 & -538.4 & -692.1 \\
\hline Current transfers & 201.5 & 241.6 & 252.1 & 217.6 & 198.4 & 227.7 & 331.0 \\
\hline Capital and financial account & 22.5 & -171.6 & -223.4 & -164.2 & -506.2 & -510.9 & -656.4 \\
\hline Capital account & 16.9 & 32.0 & 20.6 & 38.2 & 5.8 & 15.7 & 21.1 \\
\hline Financial account & 5.6 & -203.6 & -244.1 & -202.4 & -512.0 & -526.6 & -677.5 \\
\hline Direct investment & 96.1 & 92.3 & 35.2 & 55.0 & -350.7 & 30.5 & 42.7 \\
\hline Portfolio investment & -33.2 & -52.0 & -35.0 & -43.1 & -62.6 & -414.4 & -529.8 \\
\hline Other investment & -57.3 & -244.0 & -244.3 & -214.3 & -98.7 & -142.7 & -183.6 \\
\hline \multicolumn{8}{|l|}{ Of which } \\
\hline Net government long-term borrowing & 51.3 & 22.4 & -25.7 & -32.4 & -16.5 & -23.2 & -23.8 \\
\hline Other net private long-term borrowing & -10.0 & 27.5 & 1.8 & 2.0 & 2.0 & 2.1 & 3.0 \\
\hline Short-term borrowing & 71.5 & 20.3 & 46.5 & 46.1 & 76.0 & 71.4 & 93.2 \\
\hline Reserve assets (increase -) & -647.2 & -265.8 & -288.5 & -70.4 & 372.9 & 424.9 & 220.1 \\
\hline Net errors and omissions & -97.3 & 232.7 & -107.0 & -312.1 & -467.4 & -530.7 & -376.3 \\
\hline \multicolumn{8}{|l|}{ Memorandum items: } \\
\hline Current account (percent of GDP) & 13.9 & 4.1 & 12.3 & 10.4 & 11.5 & 11.6 & 11.0 \\
\hline Trade balance (percent of GDP) & 17.2 & 1.6 & 15.6 & 17.2 & 13.7 & 14.4 & 13.5 \\
\hline End-of-year reserves 2/ & 5,675 & 5,941 & 6,229 & 6,300 & 5,927 & 5,502 & 5,282 \\
\hline In months of imports of goods and services & 28.8 & 28.2 & 31.1 & 32.5 & 33.2 & 30.8 & 23.2 \\
\hline \multicolumn{8}{|l|}{ Exchange rate } \\
\hline U.S. dollars per pula (period average) & 0.2741 & 0.2380 & 0.2165 & 0.1965 & 0.1720 & 0.1585 & $\ldots$ \\
\hline U.S. dollars per pula (end of period ) & 0.2625 & 0.2243 & 0.2159 & 0.1865 & 0.1432 & 0.1829 & $\ldots$ \\
\hline
\end{tabular}

Sources: Botswana authorities; and Fund staff estimates.

1/ Based on pula-denominated estimates converted at period-average exchange rate.

2/ Includes valuation adjustment. 
Table 7. Botswana: Medium-Term Scenario, 2004-2008

\begin{tabular}{|c|c|c|c|c|c|}
\hline & 2004 & 2005 & 2006 & 2007 & 2008 \\
\hline & \multicolumn{5}{|c|}{ Projections } \\
\hline & \multicolumn{5}{|c|}{ (Annual percentage change, unless otherwise indicated) } \\
\hline \multicolumn{6}{|l|}{ National income and prices } \\
\hline Real GDP 1/ & 3.8 & 3.6 & 3.6 & 3.6 & 3.4 \\
\hline GDP deflator 1/ & 4.7 & 4.4 & 4.1 & 4.1 & 3.9 \\
\hline Consumer prices (average) & 6.5 & 6.4 & 5.8 & 5.3 & 5.0 \\
\hline Nominal GDP (in billions of pula) $1 /$ & 41.5 & 44.9 & 48.4 & 52.3 & 56.1 \\
\hline \multicolumn{6}{|l|}{ External sector } \\
\hline Exports of goods, f.o.b. (in U.S. dollar terms) & 4.0 & 1.2 & 1.4 & 1.6 & 2.0 \\
\hline Imports of goods, f.o.b. (in U.S. dollar terms) & 16.3 & 4.9 & 5.4 & 6.2 & 6.5 \\
\hline Terms of trade & -6.2 & 1.2 & 0.9 & 0.4 & 0.8 \\
\hline \multicolumn{6}{|l|}{ Central government finance $2 /$} \\
\hline Total revenue and grants & 13.4 & 11.6 & 6.2 & 6.0 & 5.8 \\
\hline \multirow[t]{2}{*}{ Total expenditure and net lending } & 8.4 & 9.7 & 7.7 & 5.3 & 5.1 \\
\hline & \multicolumn{5}{|c|}{ (Twelve-month percentage change) } \\
\hline \multicolumn{6}{|l|}{ Money and credit 3/ } \\
\hline Net claims on government & 7.3 & 2.8 & 4.5 & 4.0 & 2.2 \\
\hline Claims on private sector & 9.5 & 8.6 & 8.0 & 7.9 & 7.4 \\
\hline \multirow[t]{2}{*}{ Money and quasi money (M2) } & 9.0 & 8.4 & 8.2 & 7.5 & 7.7 \\
\hline & \multicolumn{5}{|c|}{ (In percent of GDP, unless otherwise indicated) } \\
\hline \multicolumn{6}{|l|}{ Investment and savings $1 /$} \\
\hline Gross investment & 26.6 & 27.6 & 27.9 & 30.3 & 32.7 \\
\hline Public & 13.1 & 14.0 & 13.6 & 13.1 & 11.6 \\
\hline Private & 13.5 & 13.6 & 14.2 & 17.2 & 21.1 \\
\hline Gross national savings & 32.6 & 32.3 & 31.2 & 32.6 & 34.5 \\
\hline Public & 10.4 & 12.8 & 13.9 & 13.9 & 13.9 \\
\hline Private & 22.2 & 19.5 & 17.2 & 18.7 & 20.6 \\
\hline \multicolumn{6}{|l|}{ Central government finance } \\
\hline Total revenue and grants & 48.9 & 50.4 & 49.6 & 48.7 & 47.9 \\
\hline Total expenditure and net lending & 50.0 & 50.6 & 50.6 & 49.3 & 48.2 \\
\hline Overall balance (including grants) & -1.1 & -0.3 & -1.0 & -0.6 & -0.3 \\
\hline \multicolumn{6}{|l|}{ External sector } \\
\hline External current account balance (deficit -) 3/ & 6.4 & 5.7 & 3.7 & 2.9 & 1.7 \\
\hline External debt $4 /$ & 7.1 & 6.6 & 6.2 & 5.9 & 5.5 \\
\hline \multirow[t]{2}{*}{ Total public debt (in percent of total exports) } & 21.5 & 20.6 & 20.0 & 19.5 & 19.1 \\
\hline & \multicolumn{5}{|c|}{ (In millions of U.S. dollars, unless otherwise indicated) } \\
\hline Gross official reserves (end of period) & 5,713 & 5,642 & 5,536 & 5,423 & 5,289 \\
\hline \multirow[t]{2}{*}{ (In months of imports of goods and services) } & 20.9 & 20.7 & 20.1 & 19.3 & 18.4 \\
\hline & \multicolumn{5}{|c|}{ (In percent of GDP, unless otherwise indicated) } \\
\hline \multicolumn{6}{|l|}{ Alternative scenarios } \\
\hline \multicolumn{6}{|l|}{ Alternative scenario I 5/ } \\
\hline External current account balance (deficit -) & 5.5 & 4.4 & 2.1 & 0.5 & -1.3 \\
\hline International reserves (in months of imports) & 23.2 & 20.1 & 19.3 & 18.0 & 16.3 \\
\hline Overall budget balance (deficit -) & -1.9 & -2.0 & -4.6 & -6.3 & -6.9 \\
\hline \multicolumn{6}{|l|}{ Alternative scenario II 6/ } \\
\hline External current account balance (deficit -) & 5.6 & 3.7 & 0.4 & -1.4 & -3.6 \\
\hline International reserves (in months of imports) & 22.4 & 21.4 & 19.7 & 17.5 & 15.1 \\
\hline Overall budget balance (deficit -) & -1.1 & -1.2 & -2.5 & -2.8 & -2.9 \\
\hline
\end{tabular}

Sources: Botswana authorities; and Fund staff estimates and projections.

1/ Year begins July 1.

2/ Year begins April 1.

3/ The domestic savings-investment balance in the national accounts differs from the external current account balance due to differences in timing and methodology.

4/ Medium- and long-term public and publicly guaranteed debt outstanding.

5/ An illustrative scenario incorporating HIV/AIDS programs in the National Strategic Framework.

6/ The scenario assumes diamond prices are 5 percent below the baseline levels. 
Table 8. Botswana: Central Government Operations, 2002/03-2008/09 1/

\begin{tabular}{|c|c|c|c|c|c|c|c|c|}
\hline & $2002 / 03$ & $2003 / 04$ & $2003 / 04$ & $2004 / 05$ & $2005 / 06$ & $2006 / 07$ & $2007 / 08$ & $2008 / 09$ \\
\hline & Preliminary & Budget. 2/ & Est. 3/ & \multicolumn{5}{|c|}{ IMF staff projections } \\
\hline & \multicolumn{8}{|c|}{ (In million pula) } \\
\hline Total revenue and grants & 14,311 & 17,539 & 17,107 & 19,888 & 22,195 & 23,574 & 24,989 & 26,438 \\
\hline Total revenue & 14,227 & 17,339 & 16,907 & 19,672 & 21,966 & 23,330 & 24,732 & 26,168 \\
\hline Tax revenue & 12,260 & 15,200 & 14,732 & 17,069 & 19,113 & 20,088 & 21,182 & 22,285 \\
\hline Mineral revenue & 7,503 & 8,140 & 8,140 & 8,691 & 9,872 & 10,227 & 10,569 & 10,900 \\
\hline Customs union receipts & 1,570 & 2,120 & 2,258 & 2,900 & 3,086 & 3,173 & 3,348 & 3,519 \\
\hline General sales tax/VAT & 1,245 & 2,306 & 1,700 & 2,510 & 2,828 & 3,052 & 3,292 & 3,539 \\
\hline Other & 1,942 & 2,634 & 2,634 & 2,968 & 3,325 & 3,636 & 3,973 & 4,327 \\
\hline Nontax revenue & 1,967 & 2,139 & 2,175 & 2,604 & 2,853 & 3,243 & 3,551 & 3,883 \\
\hline Interest & 225 & 170 & 170 & 185 & 201 & 217 & 234 & 251 \\
\hline Property income & 1,292 & 791 & 791 & 880 & 880 & 880 & 880 & 880 \\
\hline Other & 674 & 1,178 & 1,214 & 1,323 & 1,543 & 1,903 & 2,180 & 2,482 \\
\hline Grants & 84 & 200 & 200 & 216 & 230 & 244 & 257 & 270 \\
\hline Total expenditure and net lending & 15,703 & 18,770 & 17,384 & 20,349 & 22,322 & 24,048 & 25,312 & 26,598 \\
\hline Current expenditure & 11,581 & 13,802 & 13,801 & 15,655 & 16,606 & 17,598 & 18,555 & 19,497 \\
\hline Wages and salaries & 3,947 & 4,132 & 4,132 & 5,128 & 5,457 & 5,787 & 6,106 & 6,418 \\
\hline Interest & 81 & 107 & 107 & 209 & 168 & 166 & 164 & 164 \\
\hline Other & 7,553 & 9,562 & 9,562 & 10,318 & 10,981 & 11,645 & 12,286 & 12,915 \\
\hline Capital expenditure & 3,823 & 5,386 & 4,000 & 5,194 & 6,216 & 6,550 & 6,757 & 7,101 \\
\hline Net lending \& FAP grants & 299 & -417 & -417 & -500 & -500 & -100 & 0 & 0 \\
\hline Primary balance (deficit -) & $-1,311.1$ & $-1,124.8$ & -170.4 & -251.2 & 41.4 & -308.3 & -158.8 & 3.7 \\
\hline Overall surplus or deficit (-) & $-1,392.2$ & $-1,231.5$ & -277.4 & -460.3 & -126.7 & -474.4 & -322.6 & -160.1 \\
\hline Financing & 1,352 & 1,232 & 277 & 460 & 127 & 474 & 323 & 160 \\
\hline Foreign (net) & -250 & -265 & -265 & -140 & -85 & -85 & -30 & -10 \\
\hline Drawing & 24 & -10 & -10 & 60 & 120 & 120 & 180 & 200 \\
\hline Amortization & 274 & -255 & -255 & -200 & -205 & -205 & -210 & -210 \\
\hline \multirow[t]{2}{*}{ Domestic } & 1,602 & 1,616 & 542 & 600 & 212 & 559 & 353 & 170 \\
\hline & \multicolumn{8}{|c|}{ (In percent of GDP) } \\
\hline Total revenue and grants & 41.9 & 46.9 & 46.1 & 48.9 & 50.4 & 49.6 & 48.7 & 47.9 \\
\hline Total revenue & 41.6 & 46.4 & 45.5 & 48.3 & 49.8 & 49.1 & 48.2 & 47.4 \\
\hline Tax revenue & 35.9 & 40.7 & 39.7 & 41.9 & 43.4 & 42.2 & 41.3 & 40.4 \\
\hline Mineral revenue & 21.9 & 21.8 & 21.9 & 21.4 & 22.4 & 21.5 & 20.6 & 19.8 \\
\hline Customs union receipts & 4.6 & 5.7 & 6.1 & 7.1 & 7.0 & 6.7 & 6.5 & 6.4 \\
\hline General sales tax/VAT & 3.6 & 6.2 & 4.6 & 6.2 & 6.4 & 6.4 & 6.4 & 6.4 \\
\hline Other & 5.7 & 7.0 & 7.1 & 7.3 & 7.5 & 7.6 & 7.7 & 7.8 \\
\hline Nontax revenue & 5.8 & 5.7 & 5.9 & 6.4 & 6.5 & 6.8 & 6.9 & 7.0 \\
\hline Interest & 0.7 & 0.5 & 0.5 & 0.5 & 0.5 & 0.5 & 0.5 & 0.5 \\
\hline Property income & 3.8 & 2.1 & 2.1 & 2.2 & 2.0 & 1.9 & 1.7 & 1.6 \\
\hline Other & 2.0 & 3.2 & 3.3 & 3.3 & 3.5 & 4.0 & 4.3 & 4.5 \\
\hline Grants & 0.2 & 0.5 & 0.5 & 0.5 & 0.5 & 0.5 & 0.5 & 0.5 \\
\hline Total expenditure and net lending & 45.9 & 50.2 & 46.8 & 50.0 & 50.6 & 50.6 & 49.3 & 48.2 \\
\hline Current expenditure & 33.9 & 36.9 & 37.2 & 38.5 & 37.7 & 37.0 & 36.2 & 35.4 \\
\hline Wages and salaries & 11.5 & 11.1 & 11.1 & 12.6 & 12.4 & 12.2 & 11.9 & 11.6 \\
\hline Interest & 0.2 & 0.3 & 0.3 & 0.5 & 0.4 & 0.3 & 0.3 & 0.3 \\
\hline Other & 22.1 & 25.6 & 25.7 & 25.4 & 24.9 & 24.5 & 23.9 & 23.4 \\
\hline Capital expenditure & 11.2 & 14.4 & 10.8 & 12.8 & 14.1 & 13.8 & 13.2 & 12.9 \\
\hline Net lending & 0.9 & -1.1 & -1.1 & -1.2 & -1.1 & -0.2 & 0.0 & 0.0 \\
\hline Primary balance (deficit -) & -3.8 & -3.0 & -0.5 & -0.6 & 0.1 & -0.6 & -0.3 & 0.0 \\
\hline Overall surplus or deficit (-) & -4.1 & -3.3 & -0.7 & -1.1 & -0.3 & -1.0 & -0.6 & -0.3 \\
\hline \multicolumn{9}{|l|}{ Memorandum items: } \\
\hline GDP (fiscal year) & $34,195.0$ & $37,389.3$ & $37,147.7$ & $40,689.9$ & $44,074.1$ & $47,560.5$ & $51,297.8$ & $55,153.3$ \\
\hline
\end{tabular}

Sources: Ministry of Finance and Development Planning; and Fund staff estimates and projections.

1/ Fiscal year begins April 1 .

2/ Original budget adjusted for supplementary expenditure.

3/ Authorities' and staff estmates and projections. 
Table 9. Botswana: Balance of Payments Medium-Term Scenario, 2001-08 1/

(In millions of U.S. dollars, unless otherwise indicated)

\begin{tabular}{|c|c|c|c|c|c|c|c|c|}
\hline & 2001 & 2002 & 2003 & 2004 & 2005 & 2006 & 2007 & 2008 \\
\hline & & Est. & \multicolumn{6}{|c|}{ IMF Projections } \\
\hline Current account balance & 600.7 & 616.7 & 812.7 & 563.9 & 512.3 & 372.6 & 341.0 & 245.6 \\
\hline Trade balance & 713.8 & 763.3 & 997.7 & 788.6 & 711.3 & 620.7 & 510.9 & 393.8 \\
\hline \multicolumn{9}{|l|}{ Of which: } \\
\hline Diamonds & $1,937.1$ & $1,977.6$ & $2,482.4$ & $2,532.0$ & $2,582.7$ & $2,634.3$ & $2,687.0$ & $2,740.7$ \\
\hline \multicolumn{8}{|l|}{ Of which: } & $-2,967.2$ \\
\hline Food, beverages, and tobacco & -253.9 & -316.1 & -333.8 & -393.8 & -415.3 & -439.6 & -467.9 & -499.2 \\
\hline Chemical and rubber products & -187.5 & -216.1 & -246.5 & -290.8 & -306.7 & -324.6 & -345.5 & -368.6 \\
\hline Metal and metal products & -140.0 & -136.7 & -184.1 & -217.2 & -229.1 & -242.4 & -258.0 & -275.3 \\
\hline Machinery and electrical equipment & -357.5 & -380.0 & -470.0 & -554.4 & -584.7 & -618.8 & -658.7 & -702.8 \\
\hline Vehicle and transport equipment & -221.1 & -285.9 & -290.6 & -342.8 & -361.6 & -382.7 & -407.3 & -434.6 \\
\hline Services & -173.7 & -188.7 & -232.3 & -278.5 & -287.7 & -294.8 & -303.8 & -329.7 \\
\hline Transportation & -154.8 & -153.7 & -193.8 & -233.8 & -247.9 & -264.2 & -284.0 & -306.0 \\
\hline Travel & 26.0 & 17.6 & 29.6 & 40.3 & 51.7 & 67.2 & 85.1 & 88.8 \\
\hline Other services & -44.9 & -52.6 & -68.1 & -85.0 & -91.5 & -97.8 & -104.9 & -112.5 \\
\hline Income & -137.8 & -276.0 & -340.2 & -328.6 & -315.2 & -371.7 & -352.5 & -341.1 \\
\hline Compensation of employees & -36.8 & -38.6 & -58.5 & -68.8 & -73.9 & -79.6 & -85.3 & -91.7 \\
\hline $\begin{array}{l}\text { Investment income } \\
\text { Of which: }\end{array}$ & -101.0 & -237.4 & -288.3 & -259.7 & -241.4 & -292.1 & -267.1 & -249.5 \\
\hline Earnings on reserves & 285.0 & 266.7 & 247.6 & 237.7 & 249.9 & 253.9 & 253.6 & 247.7 \\
\hline Dividends and profits & -384.6 & -477.9 & -692.1 & -492.8 & -490.0 & -528.1 & -505.7 & -483.8 \\
\hline Current transfers & 198.4 & 227.7 & 331.0 & 382.4 & 403.9 & 418.4 & 486.4 & 522.6 \\
\hline Capital and financial account & -506.2 & -510.9 & -656.4 & -293.0 & -329.1 & -252.7 & -235.7 & -167.6 \\
\hline Capital account & 5.8 & 15.7 & 21.1 & 46.1 & 44.0 & 42.2 & 40.9 & 39.7 \\
\hline Financial account & -512.0 & -526.6 & -677.5 & -339.1 & -373.1 & -294.9 & -276.6 & -207.3 \\
\hline Direct investment & -350.7 & 30.5 & 42.7 & 53.2 & 58.0 & 63.4 & 69.6 & 76.6 \\
\hline Portfolio investment & -62.6 & -414.4 & -529.8 & -202.6 & -251.5 & -186.9 & -181.6 & -125.2 \\
\hline Other investment & -98.7 & -142.7 & -183.6 & -176.8 & -168.1 & -160.8 & -154.6 & -149.2 \\
\hline \multicolumn{9}{|l|}{ Of which: } \\
\hline Net government long-term borrowing & -16.5 & -23.2 & -23.8 & -21.2 & -21.9 & -22.6 & -23.1 & -23.5 \\
\hline Other net private long-term borrowing & 2.0 & 2.1 & 3.0 & 3.6 & 3.7 & 3.9 & 4.0 & 4.2 \\
\hline Short-term borrowing & 76.0 & 71.4 & 93.2 & 102.9 & 100.1 & 98.1 & 96.8 & 95.9 \\
\hline Net errors and omissions & -467.4 & -530.7 & -376.3 & 0.0 & 0.0 & 0.0 & 0.0 & 0.0 \\
\hline Reserve assets (increase -) & 372.9 & 424.9 & 220.1 & -270.9 & -183.1 & -120.0 & -105.3 & -78.0 \\
\hline \multicolumn{9}{|l|}{ Memorandum items: } \\
\hline Current account (percent of GDP) & 11.5 & 11.6 & 11.0 & 6.4 & 5.7 & 3.7 & 2.9 & 1.7 \\
\hline Trade balance (percent of GDP) & 13.7 & 14.4 & 13.5 & 9.0 & 7.9 & 6.6 & 5.2 & 3.8 \\
\hline End-of-year reserves 2/ & $5,926.7$ & $5,501.8$ & $5,281.7$ & $5,552.6$ & $5,735.7$ & $5,855.7$ & $5,961.0$ & $6,039.0$ \\
\hline In months of imports of goods and services & 33.2 & 30.8 & 23.2 & 20.9 & 20.7 & 20.1 & 19.3 & 18.4 \\
\hline
\end{tabular}

Sources: Botswana authorities; and Fund staff estimates and projections.

1/ For figures up to 2002, based on pula-denominated estimates converted at period-average exchange rate.

$2 /$ Includes valuation adjustment. 


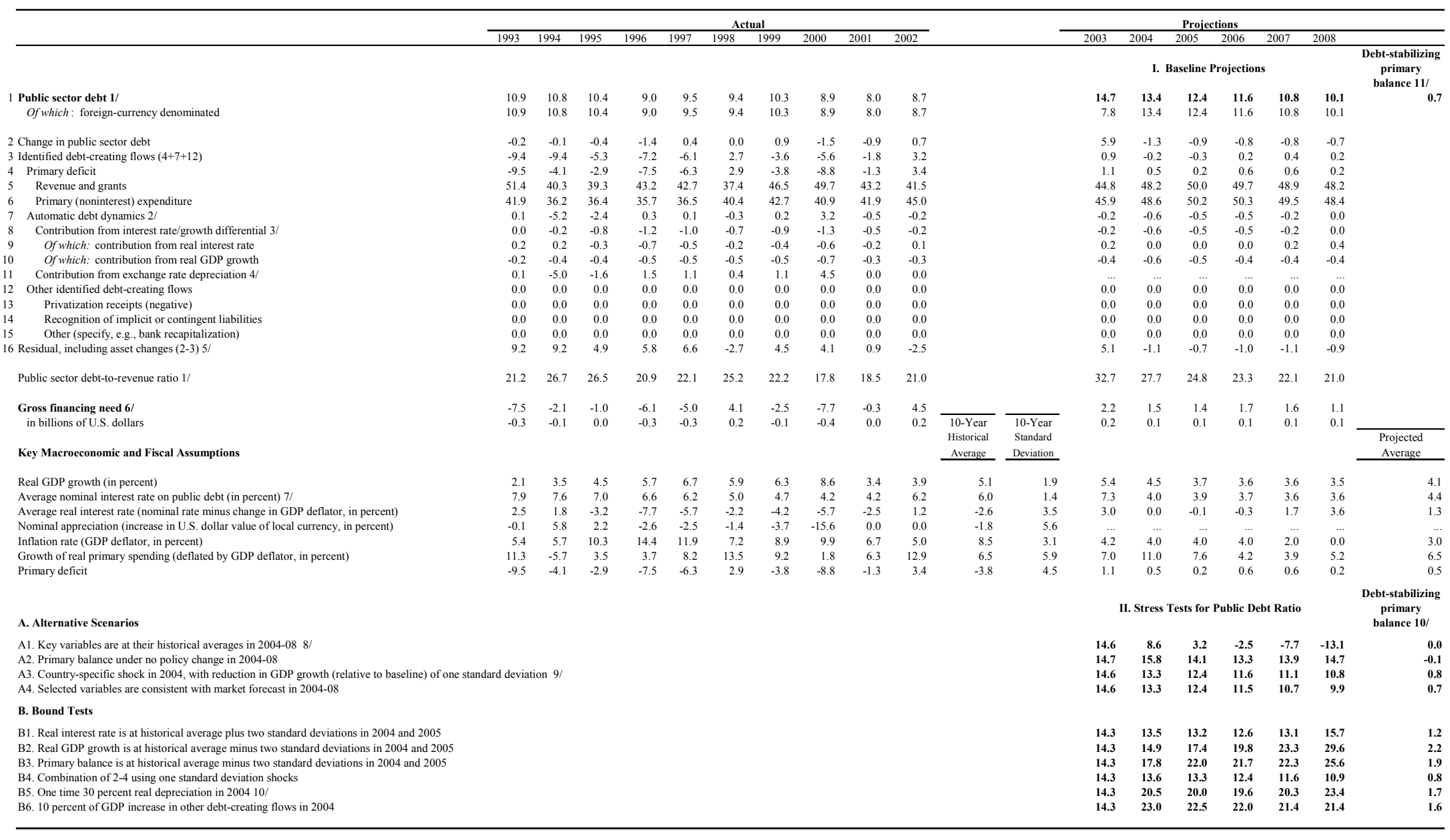

Indicate coverage of public sector, e.g., general government or nonfinancial public sector. Also whether net or gross debt is used

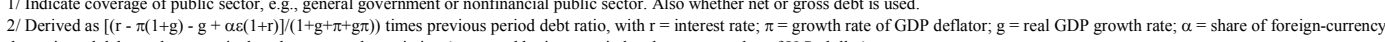

denominated debt; and $\varepsilon=$ nominal exchange rate depreciation (nessined by increase in local currency value of $U . S$. dollar).

$3 /$ The real interest rate contribution is derived from the denominator in footnote $2 /$ as $r-n(1+3)$

6/ Defined as public sector deficit, plus amortization of medium and long-term public sector debt, plus short-term debt at end of previous period

7/ Derived as nominal interest expenditure divided by previous period debs stock.

8/ The key variables in

10 / Real depreciation is defined as nominal depreciation (measured by percentage fall in dollar value of local currency) minus domestic inflation (based on GDP defflator).

11/ Assumes that key variables (real GDP growth, real interest rate, and primary balance) remain at the level in percent of GDP/growth rate of the last projection year. 
Table 11. Botswana: External Debt Sustainability Framework, 1998-2008

(In percent of GDP, unless otherwise indicated)

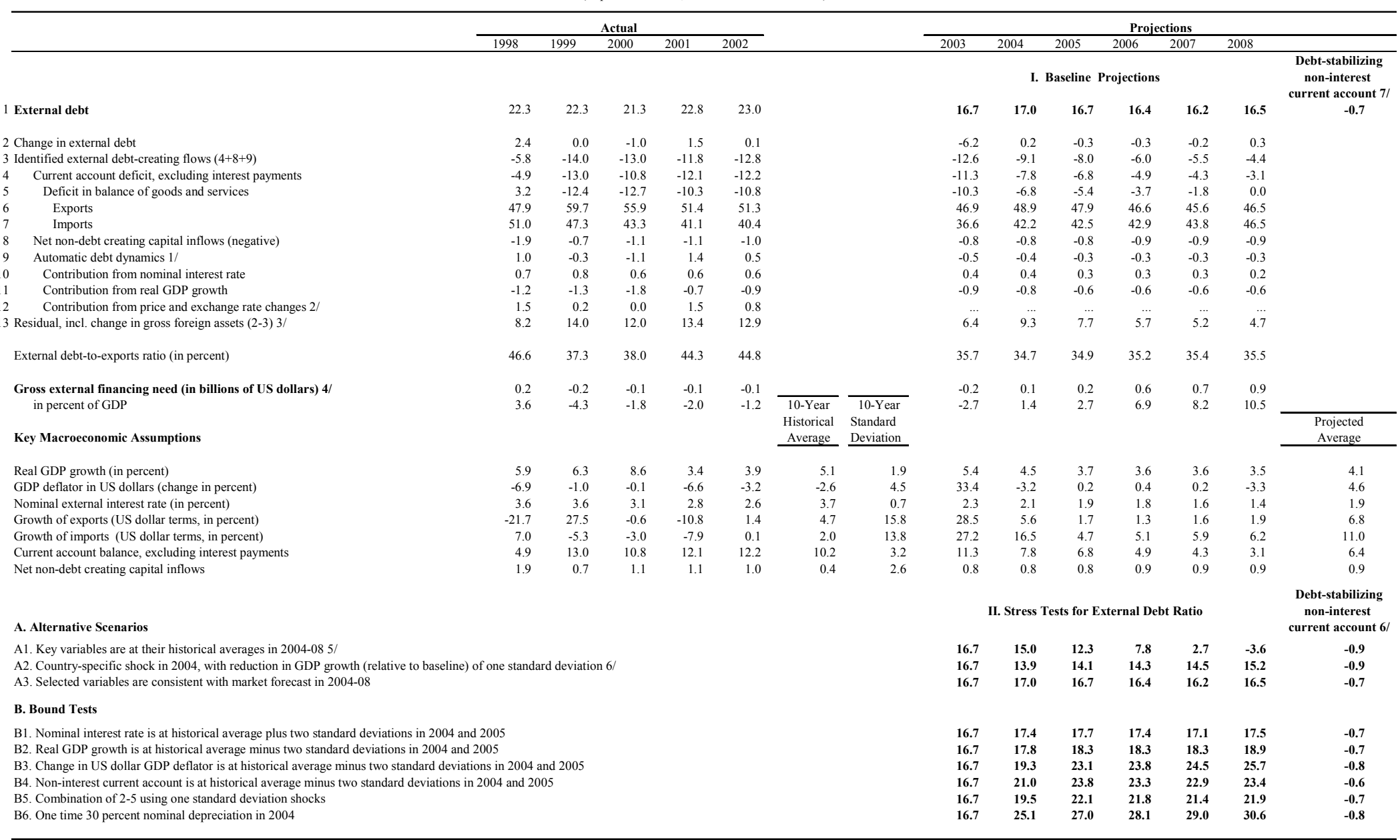

$1 /$ Derived as $[\mathrm{r}-\mathrm{g}-\rho(1+\mathrm{g})+\varepsilon \alpha(1+\mathrm{r})](1+\mathrm{g}+\rho+g \rho)$ times previous period debt stock, with $\mathrm{r}=$ nominal effective interest rate on external debt; $\rho=$ change in domestic GDP deflator in US dollar terms,

$\mathrm{g}=$ real GDP growth rate, $\mathrm{e}=$ nominal appreciation (increase in dollar value of domestic currency), and $\mathrm{a}=$ share of domestic-currency denominated debt in total external debt.

$2 /$ The contibuton from $p r i c e$ and exchange rate changes is defined as $[-\rho(1+\mathrm{g})+\varepsilon \alpha(1+\mathrm{r})](1+\mathrm{g}+\rho+\mathrm{g} \rho)$ times previous period debt stock. $\rho$ increases with an appreciating domestic currency $(\varepsilon>0)$

and rising inlation (based on GDP deflator).

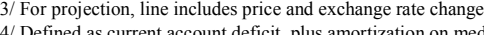

作

Long-ru

Long-run, constant balance that stabilizes the debt ratio assuming that key variables (real GDP growth, nominal interest rate, dollar deflator growth, and both non-interest current account and non-debt inflows in percent of GDP) remain
at their levels of the last projection year. 


\section{Botswana: Relations with the Fund}

(As of September 30, 2003)

I. Membership Status Joined July 24, 1968; Article VIII

$\begin{array}{lcc}\text { II. General Resources Account } & \text { SDR (million) } & \text { \% of Quota } \\ \text { Quota } & 63.00 & 100.00 \\ \text { Fund holdings of currency } & 32.69 & 51.28 \\ \text { Reserve position in Fund } & 30.32 & 48.72 \\ & & \\ \text { III. SDR Department } & \text { SDR (million) } & \text { \% of Quota } \\ \text { Net cumulative allocation } & 4.36 & 100.00 \\ \text { Holdings } & 33.52 & 768.93\end{array}$

IV. Outstanding purchases and loans None

V. Financial arrangements None

VI. Project obligations to Fund None

VII. Contribution to funding of the Enhanced Structural Adjustment Facility

In July 1994, Botswana deposited with the Fund, as trustee, an amount equivalent to US\$10 million for the benefit of the subsidy account of the Enhanced Structural Adjustment Facility (ESAF). In April 1997, Botswana made a five-year deposit of SDR 14.6 million in the ESAF-Heavily Indebted Poor Countries (HIPC) Trust.

\section{Exchange rate arrangements}

The exchange rate of the Botswana pula is determined on the basis of a basket of currencies, comprising the rand and the SDR. As of January 31,2004 , the exchange rate was US $\$ 1=$ 4.5682 .

\section{Article IV Consultation}

The last Article IV consultation was concluded by the Executive Board on October 9, 2002.

The Executive Board took the following decision:

1. The Fund takes this decision relating to Botswana's exchange measure subject to Article VIII, Section 2(a) and 3, in the light of the 2002 Article IV consultation with Botswana conducted under Decision No. 5392-(77/63), adopted April 29, 1977, as amended (Surveillance over Exchange Rate Policies). 
2. Botswana maintains a multiple currency practice subject to Fund's approval under Article VIII, Section 2(a) and 3 arising from the Foreign Exchange Risk-Sharing (FERS) scheme applicable to outstanding external loans obtained by certain public enterprises before October 1, 1990. In view of Botswana's discontinuance of the FERS in 1990 and its intention to eliminate the multiple currency practice by 2006, when the last loan under the scheme will mature, the Fund grants approval of the retention by Botswana of the multiple currency practice until March 31, 2005 or the conclusion of the next Article IV consultation with Botswana, whichever is earlier.

\section{$\mathrm{X}$. Technical assistance assignments/projects}

$\begin{array}{lll}\text { Department } & \text { Dates } & \text { Position } \\ \text { MFD } & 1997 & \text { Central banking advisor } \\ & 1999-2000 & \text { Banking supervision advisor } \\ \text { STA } & 1997 & \text { Balance of payments advisor }\end{array}$

\section{Technical assistance missions}

\begin{tabular}{|c|c|c|}
\hline Department & Dates & Purpose \\
\hline \multirow[t]{4}{*}{ MFD } & January 2001 & Banking supervision advisor \\
\hline & February 2001 & Monetary operations \\
\hline & December 2001 & MEFMI-Monetary operations \\
\hline & August 2002 & Banking supervision, anti-money laundering \\
\hline \multirow[t]{3}{*}{ FAD } & November 1997 & Introduction of a value-added-tax (VAT) \\
\hline & September 2000 & Implementation of VAT next steps \\
\hline & February 2002 & $\begin{array}{l}\text { Tax administration, Southern African Development } \\
\text { Community (SADC) region }\end{array}$ \\
\hline \multirow[t]{4}{*}{ STA } & May 2001 & $\begin{array}{l}\text { Inspection for visit for long-term balance of } \\
\text { payments advisor }\end{array}$ \\
\hline & October 2001 & $\begin{array}{l}\text { Report on Observance of Standards and Codes } \\
\text { (ROSC) data module }\end{array}$ \\
\hline & July 2002 & Balance of payments statistics: peripatetic visit \\
\hline & August 2003 & $\begin{array}{l}\text { Technical assistance on monetary and financial } \\
\text { statistics using the General Data Dissemination } \\
\text { System (GDDS) }\end{array}$ \\
\hline
\end{tabular}




\section{Botswana: Relations with the World Bank Group}

(As of September 30, 2003)

1. Botswana became a member of the World Bank and the International Development Association (IDA) in 1968, and is now a contributor to IDA. Cumulative commitments to Botswana include US\$281 million from the IBRD for 22 loans and US\$16 million from IDA for six credits. Currently, there are no active IBRD/IDA projects in Botswana.

2. Botswana joined the International Finance Corporation (IFC) in 1979 and the Multilateral Investment Guarantee Agency (MIGA) in 1988. Cumulative IFC commitments to Botswana total US\$1.8 million in three enterprises. IFC currently has one small investment in Botswana. No MIGA guarantees for investment in Botswana have been issued to date; however, Botswana has benefited from a number of MIGA's technical assistance activities and has participated in several of MIGA's annual African Mining Investment Symposia. Botswana is included in MIGA's Africa Mining CD-ROM, and its organizations are using MIGA's Internet-based Investment Promotion Network. 


\section{Botswana: Statistical Issues}

(As of December 31, 2003)

1. The core statistical data for surveillance - exchange rate, international reserves, reserve/base money, the central bank balance sheet, broad money, interest rates, and consumer price index data - are available on a monthly basis and are reported to the Fund with an acceptable degree of regularity and promptness. In general, the quality of these data is adequate to conduct surveillance. The authorities have started generating quarterly data for the national accounts and balance of payments. However, the time lag in compiling the national accounts and labor market data needs to be reduced. Intensified efforts are needed to develop a unified accounting period for preparing and presenting economic data; the current arrangements - according to which the balance of payments statistics are compiled on a calendar-year basis, and the national accounts and the budget on July-June and April-March bases, respectively - impede the preparation of an integrated set of economic data. Most economic data are made available to the general public through a number of official publications, including the Annual Report and Botswana Financial Statistics of the Bank of Botswana, the Annual Economic Report of the Ministry of Finance and Development Planning, and the Statistical Bulletin of the Central Statistics Office (CSO).

2. Missions for the data module of the Report on the Observance of Standards and Codes (ROSC) were conducted in October and December of 2001, and the Report was disseminated on Fund's external website in April 2002. Botswana is participating in the General Data Dissemination Standard (GDDS), and its metadata were initially posted on the Dissemination Standards Bulletin Board in October 2002.

3. Furthermore, the mission observed that Botswana's statistics-producing agencies have a legal and institutional framework that supports statistical quality and demonstrate an awareness of quality as the cornerstone of statistical work. Resources are mostly commensurate with the needs of current statistical programs, but may be inadequate for the further development of statistical systems.

\section{Real sector}

4. The CSO compiles and disseminates annual and quarterly national accounts in current and constant prices, using the production and expenditure approach. The national accounts are based primarily on the concepts and definitions recommended by the 1968 System of National Accounts (SNA). The differences in the accounting periods and in the timing of recording among the national accounts, balance of payments, and government finance statistics have an impact on the accuracy of the estimates compiled. Annual employment and wage information are available but are rarely reported to STA for publication in the International Financial Statistics (IFS). 
5. The consumer price index is comprehensive and provides a breakdown of the index between urban and rural areas, as well as between tradables (domestic and imported) and nontradables. In early 1997, the index was rebased from November 1991 to November 1996, and the weights were changed to reflect the findings of the 1993/94 Household Income and Expenditure Survey. With respect to the producer price index, the data could be improved through the collection of more comprehensive source data and the adoption of best international practice for the data compilation.

\section{Fiscal accounts}

6. Central government finance data for publication in the IFS are reported with a two-to three-month lag. The timeliness of the reporting can be improved, as these data are produced monthly, with a lag of three to four weeks, for use in the Ministry of Finance and Development Planning (MFDP). No annual government finance data for publication in the Government Finance Statistics Yearbook (GFSY) have been reported since 1996. However, comprehensive annual government finance statistics on the consolidated central government are published by the authorities with a 12-month lag after the end of the reference year in the MFDP's Annual Statements of Accounts.

7. Compilation and dissemination of central government finance data are largely based on the methodology of the IMF's Manual on Government Finance Statistics (GFSM 1986) and cover all central government activities, including balances of financial assets and liabilities of the central government units. The classification of revenue, expenditure, and financing data, is broadly consistent with the 1986 methodology, with a few exceptions. Monthly data are compiled, but the level of accuracy is less than for audited annual fiscal data, which are made available with a 12-month lag. The monthly data are available for internal use by Ministry of Finance and Development Planning, and are timely (with a lag of less than a month after the end of the reference month; but up to three months for March, the last month of the fiscal year). Most data are sufficiently detailed for government finance statistics purposes, but source data could be improved to allow the consolidation of general government statistics. In general, the published data have been audited by the Auditor General Accuracy and reliability are clearly favored at the expense of timeliness.

\section{Monetary accounts}

8. In compiling the monetary survey, the Bank of Botswana follows broadly the methodology recommended in the Fund's Monetary and Financial Statistics Manual (MFSM). However, the monetary survey does not cover four deposit-taking institutions (two merchant banks, one building society, and one savings bank), which account for about 5 percent of the deposits of the system. 
9. Monetary data for publication in IFS are reported on a regular basis. The timeliness of reporting has improved since 2002 . However, data for the monetary authorities are still being reported to STA with a longer lag (one additional month) than those for the deposit money banks.

\section{External trade and balance of payments}

10. Botswana reports data annually on the balance of payments and the international investment position. A resident IMF balance of payments statistics advisor assigned to the Bank of Botswana in October 1997 concluded his term in July 2000. The project helped establish the Balance of Payments Manual, fifth edition, as the basis for balance of payment statistics, revised the Foreign Investment Survey, contributed to the development of quarterly statistics, and improved estimation methodologies. However, delays in supplying source data are a major concern and hamper efforts to improve the timeliness of statistics. Balance of payments statistics are compiled in conformity with internationally accepted statistical frameworks, but methods for their estimation need to be updated. While procedures underlying the compilation of data are sound, some estimation methods need to be updated. In 2003, Botswana received technical assistance in the context of the General Data Dissemination System project for Anglophone Africa, which resulted in the establishment of a framework for quarterly balance of payments data. A resolution of discrepancies between the balance of payments and the national accounts, improved coverage of investment flows, and issues on Southern African Customs Union-related payments in the balance of payments is pending. 
Botswana: Core Statistical Indicators

(As of October 1, 2003)

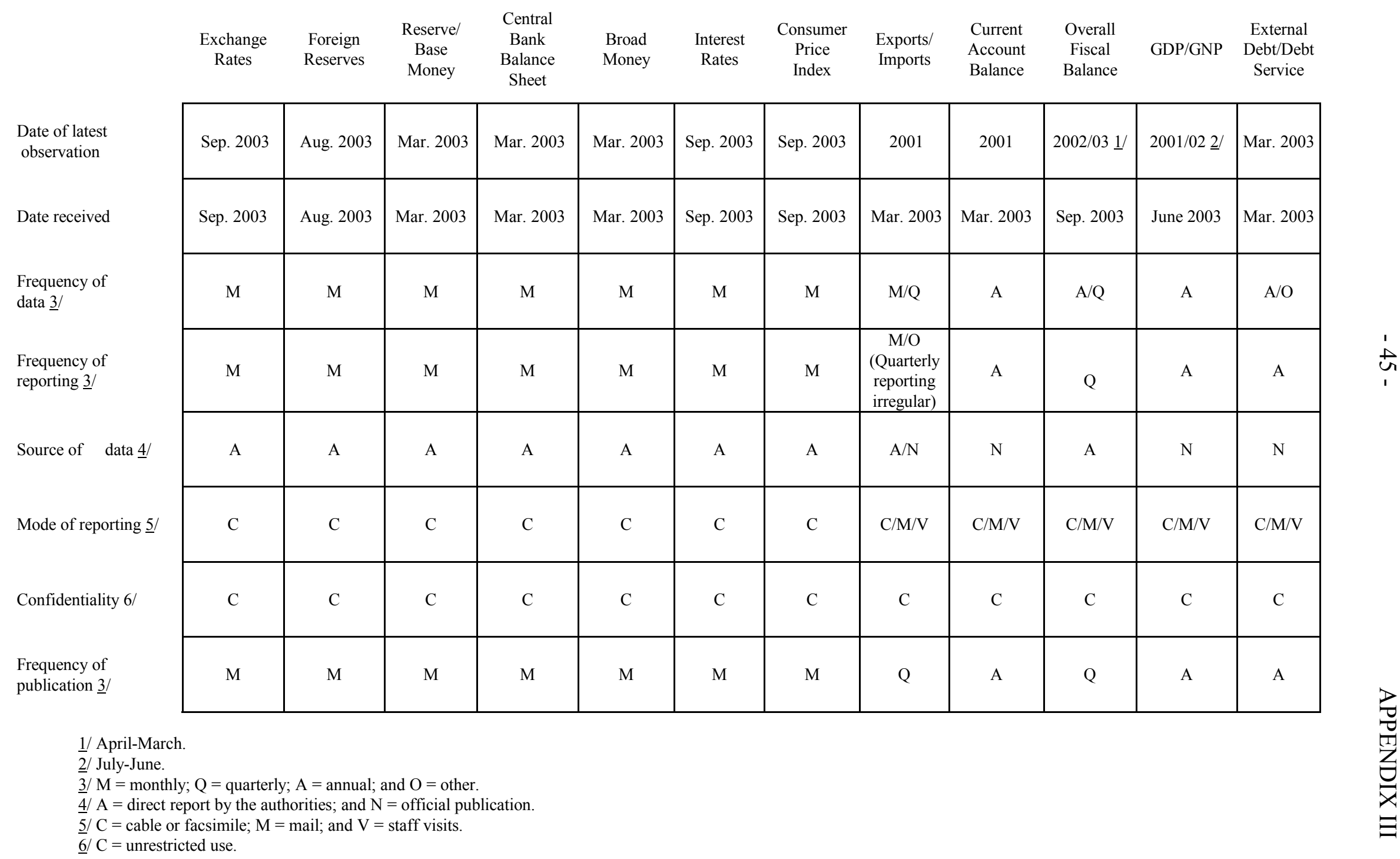




\section{Botswana: Social and Demographic Indicators}

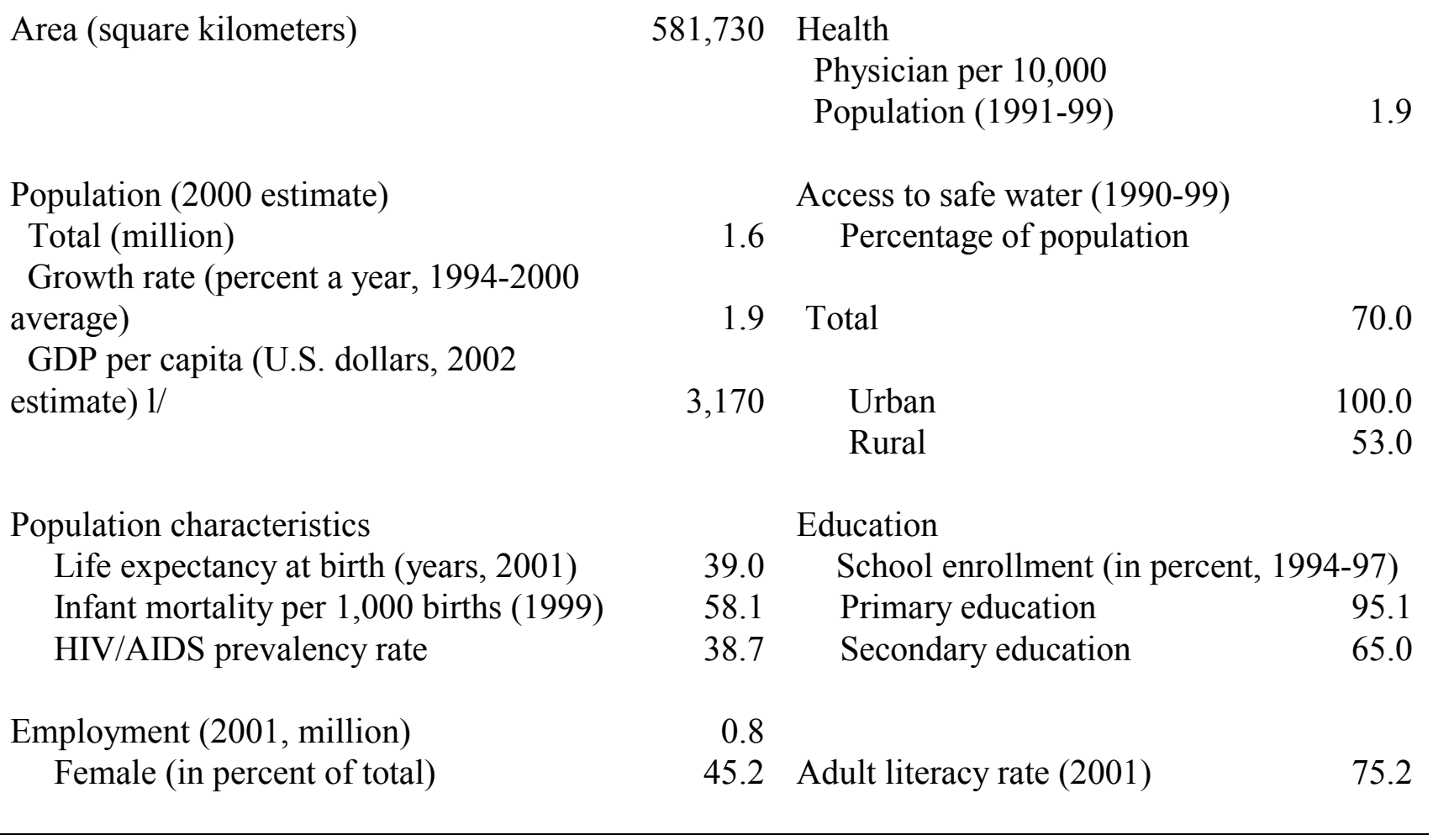

Source: World Bank, World Development Indicators, 2003.

1/ Staff estimate. National accounts year beginning July 1. 


\title{
INTERNATIONAL MONETARY FUND
}

\section{BOTSWANA \\ Staff Report for the 2003 Article IV Consultation Supplementary Information}

\author{
Prepared by the African Department \\ (In consultation with the Legal and Policy Development and Review Departments) \\ Approved by Juan Carlos Di Tata and Anthony Boote
}

March 23, 2004

1. This supplement provides further information on the preliminary budget outturn for $2003 / 04$ and the 2004/05 budget, which became available since the staff report for the 2003 Article IV Consultation was issued on March 10, 2004. This information does not change the thrust of the staff appraisal, as the medium-term fiscal outlook remains in line with the report's projections.

2. Revised estimates for the 2003/04 (April-March) budget indicate an overall deficit of 0.1 percent of GDP, which is slightly below the estimate included in the staff report (See chart and Table 1). Mineral revenue fell short of the estimate in the staff report by about 4 percentage points of GDP, mainly because of the pula appreciation against the U.S. dollar (by about 18 percent) in 2003. To offset this revenue shortfall, the government implemented an across-the-board reduction of 5 percent in recurrent expenditure and reduced net lending by selling its portfolio of public enterprise loans.

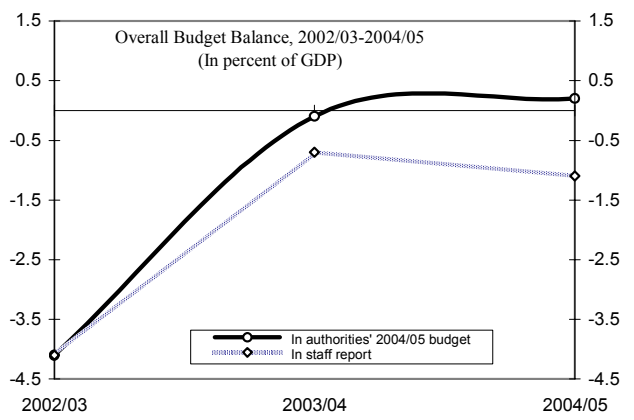

3. The 2004/05 budget, presented to parliament on February 9, 2004, envisages an overall surplus of 0.2 percent of GDP. Total revenue, including grants, is projected to increase by 1.2 percentage points of GDP relative to 2003/04, owing mainly to the impact of the recent pula devaluation against the U.S. dollar on mineral and customs revenue, and measures to close loopholes and improve tax administration. At the same time, total expenditure (including net lending) is projected to increase by 1 percentage point of GDP. Specifically, the budget envisages an increase in expenditure of close to 3 percentage points of GDP to cover (i) a 15 percent wage increase (there was none in 2003/04) as part of the public service pay restructuring; (ii) a 10 percent increase in pensions and allowances to support vulnerable groups; and (iii) an increase in health expenditure (including on HIV/AIDS) to 10 percent of total expenditure, from 9 percent in 2003/04. To partially offset these additional outlays - as well as those related to the first round effect of the devaluation on government imports and external debt service - the budget envisages a reduction in other noninterest recurrent expenditure and capital outlays of over 2 percentage points of GDP. In the budget speech, the Minister of Finance said that the revenue projections were subject to significant uncertainty. 
Table 1. Botswana: Central Government Operations, 2000/01-2004/05 1/

\begin{tabular}{|c|c|c|c|c|c|c|c|}
\hline & $2000 / 01$ & $2001 / 02$ & $\begin{array}{r}2002 / 03 \\
2 / \\
\end{array}$ & $\begin{array}{r}2003 / 04 \\
\text { Budget.3/ } \\
\end{array}$ & $\begin{array}{r}2003 / 04 \\
\text { est. } 4 / \\
\end{array}$ & $\begin{array}{r}2003 / 04 \\
\text { rev. } 5 / \\
\end{array}$ & $\begin{array}{r}2004 / 05 \\
\text { Budget } \\
\end{array}$ \\
\hline & \multicolumn{7}{|c|}{ (In million pula) } \\
\hline Total revenue and grants & 14,115 & 12,708 & 14,311 & 17,539 & 17,107 & 16,182 & 18,209 \\
\hline Total revenue & 14,051 & 12,649 & 14,227 & 17,339 & 16,907 & 15,982 & 18,009 \\
\hline Tax revenue & 12,078 & 10,582 & 12,259 & 15,200 & 14,732 & 13,044 & 16,097 \\
\hline Mineral revenue & 8,368 & 6,996 & $7,502.7$ & 8,140 & 8,140 & $6,721.0$ & $8,070.4$ \\
\hline Customs Union receipts & 2,188 & 1,732 & $1,568.9$ & 2,120 & 2,258 & $2,262.5$ & $3,293.8$ \\
\hline General sales tax/VAT & 524 & 520 & $1,254.6$ & 2,306 & 1,700 & $1,725.1$ & $2,070.0$ \\
\hline Other & 998 & 1,334 & $1,933.3$ & 2,634 & 2,634 & $2,335.2$ & $2,662.9$ \\
\hline Nontax revenue & 1,973 & 2,067 & 1,967 & 2,139 & 2,175 & $2,938.4$ & $1,911.9$ \\
\hline Interest & 205 & 189 & 226.8 & 170 & 170 & 170.2 & 58.5 \\
\hline Property income & 1,195 & 1,170 & $1,063.9$ & 791 & 791 & $1,136.1$ & 469.6 \\
\hline of which Bank of Botswana revenue & 1,167 & 1,066 & $1,028.9$ & 755 & 755 & 755.0 & 434.0 \\
\hline Other & 573 & 708 & 676.5 & 1,178 & 1,214 & $1,632.1$ & $1,383.7$ \\
\hline Grants & 65 & 59 & 84.4 & 200 & 200 & 200.0 & 200.0 \\
\hline Total expenditure and net lending & 11,536 & 13,670 & 15,710 & 18,770 & 17,384 & 16,207 & 18,140 \\
\hline Current expenditure & 8,383 & 9,935 & 11,581 & 13,802 & 13,801 & 13,258 & 14,571 \\
\hline Wages and salaries & 2,743 & 3,924 & $3,946.5$ & 4,132 & 4,132 & $3,941.2$ & $4,775.6$ \\
\hline Interest & 83 & 94 & 81.1 & 107 & 107 & 220.2 & 353.2 \\
\hline Other & 5,557 & 5,917 & $7,553.4$ & 9,562 & 9,562 & $9,096.6$ & $9,441.8$ \\
\hline Capital expenditure & 3,135 & 3,698 & $4,200.2$ & 5,386 & 4,000 & $4,000.0$ & $3,610.0$ \\
\hline Net lending \& FAP grants & 19 & 37 & -71.2 & -417 & -417 & $-1,051.3$ & -40.4 \\
\hline Primary balance (deficit -) & 2,662 & -868 & $-1,317.9$ & $-1,125$ & -170.4 & 195.7 & 422.0 \\
\hline Overall surplus or deficit (-) & 2,579 & -962 & $-1,399.1$ & $-1,232$ & -277.4 & -24.4 & 68.8 \\
\hline Financing & $-2,579$ & 962 & $1,399.1$ & 1,232 & 277.4 & 24.4 & -68.8 \\
\hline Foreign (net) & -177 & -184 & -250.0 & -265 & -264.8 & -129.3 & -89.5 \\
\hline Drawing & 13 & 60 & 23.5 & -10 & -10.0 & 135.5 & 97.3 \\
\hline Amortization & -190 & -244 & -273.5 & -255 & -254.8 & -264.8 & -186.9 \\
\hline \multirow[t]{2}{*}{ Domestic } & $-2,401$ & 1,169 & $3,103.4$ & 1,616 & 542.1 & 153.7 & 20.8 \\
\hline & \multicolumn{7}{|c|}{ (In percent of GDP) } \\
\hline Total revenue and grants & 50.9 & 40.8 & 41.9 & 47.2 & 46.1 & 43.6 & 44.8 \\
\hline Total revenue & 50.7 & 40.6 & 41.6 & 46.7 & 45.5 & 43.0 & 44.3 \\
\hline Tax revenue & 43.5 & 34.0 & 35.9 & 40.9 & 39.7 & 35.1 & 39.6 \\
\hline Mineral revenue & 30.2 & 22.4 & 21.9 & 21.9 & 21.9 & 18.1 & 19.8 \\
\hline Customs Union receipts & 7.9 & 5.6 & 4.6 & 5.7 & 6.1 & 6.1 & 8.1 \\
\hline General sales tax/VAT & 1.9 & 1.7 & 3.7 & 6.2 & 4.6 & 4.6 & 5.1 \\
\hline Other & 3.6 & 4.3 & 5.7 & 7.1 & 7.1 & 6.3 & 6.5 \\
\hline Nontax revenue & 7.1 & 6.6 & 5.8 & 5.8 & 5.9 & 7.9 & 4.7 \\
\hline Interest & 0.7 & 0.6 & 0.7 & 0.5 & 0.5 & 0.5 & 0.1 \\
\hline Property income & 4.3 & 3.8 & 3.1 & 2.1 & 2.1 & 3.1 & 1.2 \\
\hline of which Bank of Botswana revenue & 4.2 & 3.4 & 3.0 & 2.0 & 2.0 & 2.0 & 1.1 \\
\hline Other & 2.1 & 2.3 & 2.0 & 3.2 & 3.3 & 4.4 & 3.4 \\
\hline Grants & 0.2 & 0.2 & 0.2 & 0.5 & 0.5 & 0.5 & 0.5 \\
\hline Total expenditure and net lending & 41.6 & 43.9 & 45.9 & 50.5 & 46.8 & 43.6 & 44.6 \\
\hline Current expenditure & 30.2 & 31.9 & 33.9 & 37.2 & 37.2 & 35.7 & 35.8 \\
\hline Wages and salaries & 9.9 & 12.6 & 11.5 & 11.1 & 11.1 & 10.6 & 11.7 \\
\hline Interest & 0.3 & 0.3 & 0.2 & 0.3 & 0.3 & 0.6 & 0.9 \\
\hline Other & 20.0 & 19.0 & 22.1 & 25.7 & 25.7 & 24.5 & 23.2 \\
\hline Capital expenditure & 11.3 & 11.9 & 12.3 & 14.5 & 10.8 & 10.8 & 8.9 \\
\hline Net lending & 0.1 & 0.1 & -0.2 & -1.1 & -1.1 & -2.8 & -0.1 \\
\hline Primary balance (deficit -) & 9.6 & -2.8 & -3.9 & -3.0 & -0.5 & 0.5 & 1.0 \\
\hline Overall surplus or deficit (-) & 9.3 & -3.1 & -4.1 & -3.3 & -0.7 & -0.1 & 0.2 \\
\hline \multicolumn{8}{|l|}{ Memorandum items: } \\
\hline GDP (fiscal year) & $27,739.3$ & $31,167.9$ & $34,195.0$ & $37,147.7$ & $37,147.7$ & $37,147.7$ & $40,689.9$ \\
\hline
\end{tabular}

1/ Fiscal year begins April 1.

2 / Revised actual contained in 2004/05 budget.

3/ Original budget adjusted for supplementary expenditure

4/ Authorities' and staff estimates and projections.

5/ Authorities' revised estimates in the context of the 2004/05 Budget. 


\section{Statement by Ismaila Usman, Executive Director for Botswana and Peter J. Ngumbullu, Alternate Executive Director March 24, 2004}

The Botswana authorities are grateful to staff for the candid exchange of views during the 2003 Article IV Consultation discussions. The authorities also agree with the thrust of the staff assessment presented in the report, which they view as fair and balanced. We have received communication from the authorities that they consent to the publication of the staff report and related documents subject to the correction of factual errors and deletion of certain confidential information.

\section{Background}

Botswana has recorded the highest rate of GDP per capita growth of any country in the world in the last three decades. This occurred despite initial adverse conditions, including minimal investment during the colonial period and the prevailing high income inequality. Diamond production currently accounting for around 40 percent of the country's output has been important for growth in Botswana. However, diamond production is not the main reason for the country's remarkable economic performance. In many countries, natural resource abundance appears to be a curse rather than a blessing, as it has led to weak policy implementation and even conflicts. In contrast, a major factor contributing to Botswana's spectacular growth performance has been the pursuit of prudent macroeconomic and fiscal policies. For instance, the Growth Competitiveness Index (GCI) of the 2003 Global Competitiveness Report, ranks Botswana number 36 out of a total of 102 countries. In Africa, Botswana has the highest ranking in the GCI, including the ranking of public institutions and macroeconomic policies in the region. In the sub index on public institutions, Botswana is ranked number 26, ahead of Japan, Spain, and Italy. In terms of the Transparency International Corruption Index for 2003, Botswana is perceived to be the least corrupt country in Africa and the $30^{\text {th }}$ least corrupt country in the world ${ }^{1}$. Botswana also enjoys the highest sovereign credit rating on the African continent. Notwithstanding the excellent track record, the authorities recognize that the country faces enormous developmental challenges, including having one of the highest incidences of HIV/AIDS, and a narrow economic base. The authorities have responded to these challenges, have made good progress in several areas, and their strategy going forward is sound. Recently, a number of necessary corrective measures were incorporated in the Ninth National Development Plan.

\section{Recent Economic Developments and Prospects}

The economic fundamentals in Botswana remain sound: Real GDP is estimated to have grown by 6.7 percent in 2002/03, based on constant 1993/94 prices and inflation declined

\footnotetext{
${ }^{1}$ The Corruption Perceptions Index (CPI), in 2003 ranked 133 countries in terms of the degree to which corruption is perceived to exist among public officials and politicians.
} 
from over 11 percent in 2002 to 6.4 percent in 2003. The overall revised budget deficit for fiscal year 2003/04 is set at 0.1 percent of GDP. Employment has been growing and about 15,000 formal sector jobs were added to the labor force between 2001 and 2003. Looking ahead, the Ninth National Development Plan (NDP 9) projects real GDP growth at just over 5 percent in 2003/04 and 2004/05. Beyond 2004/05, growth will depend largely on the authorities success in enhancing the performance of the non-mining sectors, which is at the heart of the authorities ongoing efforts to diversify the economy. Supported by prudent fiscal and monetary policies and coupled with efficiency enhancement in the economy, the Botswana authorities are confident that the real growth of the non-mining sector will continue. Total revenue and grants for the 2004/05 financial year are estimated at P18.2 billion, while total expenditures set at P18.1 billion, resulting in a small surplus of about 0.2 percent of GDP. In the light of the recent series of budget deficits, the authorities are committed to the attainment of a balanced budget. The authorities affirm their commitment to eliminate the fiscal deficit and to improve the conditions for private initiative and job creation.

\section{Fiscal Policy}

Botswana will continue to pursue prudent fiscal management anchored in the Ninth National Development Plan (NDP9) and the overarching principle of sustainability. The 2003/04 has been adversely affected by the international exchange rate and price developments. Since early 2002, the US dollar has weakened dramatically against the Pula and other international currencies, but diamond prices did not increase significantly to compensate for the weakness of the US dollar. In addition revenue from the introduction of value-added-tax (VAT), replacing the domestic sales tax in July 2002, did not meet expectations; while expenditure on HIV/AIDS and drought relief exceeded expectation. In this connection, several remedial measures have been taken by the government to achieve a balanced budget during fiscal year 2003/04, including:

(a) The Minister of Finance invoked Section 14(2) of the Finance and Audit Act to withdraw 5 percent of the 2003/04 recurrent budget.

(b) The development budget has been scaled back to P4.0 billion by asking ministries to exercise strict cost controls and to prioritize their development expenditure.

(c) The sale of the Public Debt Service Fund (PDSF) loan book is proceeding well and the bulk of the loan book will be sold by the end of this financial year.

(d) Government expects dividend payment from a number of profitable state owned enterprises.

Putting all these measures together would result in an overall budget deficit of 0.1 percent of GDP for the financial year 2003/04.

Looking ahead, for the 2004/05 budget the revenue picture remains uncertain. Minerals and customs and excise revenue depend crucially in what happens to the US dollar and the South 
African Rand in the international currency market. However, the authorities are more optimistic regarding VAT revenue. Implementation of VAT has been a learning process for both taxpayers and government. The authorities, believe that taxpayers now understand the system, a fact that will benefit the full enforcement of the VAT law in 2004 with enhanced auditing capabilities. In order to improve tax collections, in November of 2003, the cabinet approved the setting up of the Botswana Unified Revenue Service (BURS); legislation is pending parliamentary approval and the BURS is expected to begin operations later this year.

On the expenditure side, the development budget for fiscal year 2004/05 has been reduced compared with the preceding fiscal year. Given the financial constraints only ongoing projects as well as those for which contracts had already been awarded, have been included in the new budget. In implementing the development budget for 2004/05, the authorities will insist on efficiency gains on all projects. This will require scaling down the scope, specifications and standard of materials to the funds allocated, and the way tenders are specified, in order to achieve efficiency gains on consultancy charges. The authorities have also adopted Public Private Partnership (PPPs) as a procurement method, which should provide further cost savings in project implementation. Should the revenue situation turn out to be significantly worse than forecast in the budget, the authorities would consider further expenditure cuts during the course of the fiscal year.

\section{Monetary, Exchange Rate and Financial Sector Issues}

Monetary policy is anchored on Botswana's exchange rate peg to a basket comprising the South African Rand and the SDR. The primary long-term objective of monetary policy is the achievement of low and sustainable inflation. The staff report correctly identifies the two main challenges facing monetary policy going forward, namely the need to strengthen the framework for monetary management given the ongoing reforms and development of the financial sector, and the importance of better coordination between monetary and fiscal policy in order to avoid undue pressures on interest rates and the exchange rate as the economy adjust to changes in the economic and financial environment resulting from plateauing in diamond production and HIV/AIDS. The authorities also welcome the staff analysis of recent financial sector developments and reforms, and the monetary policy framework included in Section II and IV of the selected issues and statistical appendix. They are timely and will assist the authorities own research on these issues.

Nevertheless, there are a few issues the authorities would like to highlight. During 2003, the real effective exchange rate of the Pula appreciated, which indicates some loss of competitiveness. To correct this situation, the Pula was devalued by 7.5 percent against the basket in February 2004. The main reason for the cause of REER appreciation in recent years is relative prices (higher inflation in Botswana than in trading partners) and not NEER appreciation. The devaluation was taken into account in setting the 2004 inflation objective of 4-7 percent. The devaluation will have some impact on the inflation, and some will be accommodated. Accordingly, the focus of monetary policy stance in 2004 will be to minimize the initial inflationary impact of higher import prices, and to ensure that these are not passed through to a second round impact on domestic prices. The authorities believe that 
the current composition of the currency basket weights, based on non-diamond trade patterns is appropriate.

The Bank of Botswana is implementing a number of reforms to strengthen the conduct of monetary policy; including:

(a) Greater transparency in monetary management.

(b) Enhancing the public's understanding of the policy transmission mechanism.

(c) Improving the functioning of the money market and the effectiveness of monetary policy.

In this connection, the authorities thank the Fund for the technical assistance rendered in enhancing inflation modeling capabilities of the Bank of Botswana.

The authorities broadly agree with the staff's overall assessment of Botswana's financial system. The banking industry is financially sound, solvent, profitable and highly liquid, with banks maintaining prudential ratios in excess of statutory requirements, and low ratios of non-performing loans. They have requested the Fund's technical assistance to set up an autonomous Financial Supervisory Authority to regulate and supervise non-bank financial institutions, and they are currently reviewing the existing anti-money laundering legislation (AML), to determine if a separate AML law is needed. However, the authorities emphasize that the current legislation, which is not contained in one unified code does have provision for anti-money-laundering.

\section{Economic Diversification and Structural Issues}

One of the main concerns of the Botswana authorities is the diversification of the economy. This concern is echoed in the 2004 budget speech entitled "Improving Economic Performance: A Vehicle for Sustainable and Diversified Development." The plateauing of diamond production further underscores the need for diversification, and the objective of diversification has been given paramount importance under the NDP9. The plan envisages a number of structural reforms targeted at supporting private sector led investment, especially targeting the non-traditional non-mining sectors as well as the financial sector. The International Financial Services Centre (IFSC) was established in 1999, with the main objective of increasing employment and expertise in financial services, in order to make Botswana a financial hub for Sub-Saharan Africa. So far the success of the IFSC has been limited, and as at end 2003, only 20 companies were operating under the IFSC. Other initiatives include the establishment of the Citizen Entrepreneurial Development Agency (CEDA), in 2001, the CEDA Venture Capital Fund in 2003, and the Credit Guarantee scheme. The Authorities have also set up a one-stop investment center, the Botswana Export Development and Investment Authority (BEDIA), aimed at promoting non-traditional export sectors. A study identifying barriers to investment, by the IFC has recently been concluded and the authorities will urgently consider the findings and recommendations relevant both to the resilience of the economy in the face of external shocks and potential growth in the medium and long-term. 


\section{Health and HIV/AIDS}

The Botswana Authorities take the HIV/AIDS pandemic very seriously and are addressing the challenges head on. In this connection the government has developed a medium-term program, the National Strategic Framework (NSF) for HIV/AIDS (2002-2009), with the ultimate goal of having an HIV/AIDS free generation by 2016. The framework presents a systematic, multisectoral approach to managing the pandemic, and has established the National AIDS Coordinating Agency (NACA), chaired by President Festus Mogae, as the focal point for facilitating and coordinating various HIV/AIDS interventions in the country. The NSF is anchored on the goals of prevention, care and support, management of the national response, economic impact mitigation, and provision of strengthened legal and ethical environment. The treatment of the pandemic focuses on the administration of antiretroviral drugs to the infected; prevention of mother-to-child transmission; the treatment of TB, and opportunistic and sexually transmitted diseases, and voluntary counseling and testing. Beginning 2004, the government has introduced routine voluntary HIV testing, as part of the efforts to address the stigma associated with HIV/AIDS. The Antiretroviral (ARV) therapy started at the beginning of 2002 has been rolled out to seven additional cities. The Prevention of Mother-To-Child Transmission (PMTCT) program is now available in all public health facilities country wide. As indicated in the selected issues paper the budgetary implications of the HIV/AIDS program over the period 2002/03 to 2007/08 would be in the order of 5 percent of GDP. The Botswana authorities thank the international community for the support rendered, thus far in fighting this dreadful disease, which is a global problem.

\section{Other Issues}

The Botswana authorities are committed to strengthening the statistical system, through implementation of the recommendations of the data module of the Report on Observance of Standards and Codes (ROSC) concluded in 2001. They accepted the recommendations of the updated ROSC. So far a fair number of the recommendations have already been implemented, but work is ongoing. It should, however be noted that government has already decided to transform the central statistics office (CSO) into an autonomous institution. What remains to be done is to work out the modalities and timing. The authorities will continue with trade reforms in the context of SADC and SACU. They also actively participate in negotiations aimed at achieving permanent access to major international markets, through the proposed SACU-USA free trade agreement and a new regional Economic Partnership Agreement (EPA) with the European Union.

In conclusion, we believe the continued dialogue between the authorities and the staff has been fruitful. We want to reiterate the strong commitment of the authorities in the reforms and in addressing the economic challenges ahead. In this regard, we hope that the Fund will be fully responsive in providing the technical assistance requested by the authorities to strengthen their ability to implement the necessary reforms. 


\section{INTERNATIONAL MONETARY FUND}

EXTERNAL

Public Information Notice

RELATIONS

DEPARTMENT

Public Information Notice (PIN) No.04/78

FOR IMMEDIATE RELEASE

International Monetary Fund

July 30, 2004

$70019^{\text {th }}$ Street, NW

Washington, D. C. 20431 USA

\section{IMF Concludes 2003 Article IV Consultation with Botswana}

On March 24, 2004, the Executive Board of the International Monetary Fund (IMF) concluded the Article IV consultation with Botswana. ${ }^{1}$

\section{Background}

Botswana has been among the best-performing economies over the past 35 years. During this period, Botswana has evolved from one of the poorest countries in the world to a middle-income country with the highest sovereign credit rating in Africa. This success has been widely attributed to sound economic policies, especially in managing its large diamond resources, and a commitment to democratic principles. However, Botswana remains heavily dependent on the diamond sector, which is reaching a production plateau; the diamond sector accounts for about one-third of GDP and 70 percent of export earnings. Botswana also has one of the highest HIVIAIDS infection rates, which threatens to unravel its economic success to date.

Faced with these problems, Botswana's major challenge is to develop appropriate social safety nets and diversify the economy to support economic growth, which is expected to decelerate relative to the high rates experienced over the past 35 years. In April 2003, Botswana launched the Ninth National Development Plan (NDP 9) for 2003/04-2008/09, which focuses on diversifying the economy away from mineral production and exports and addresses the problems of unemployment, poverty reduction, and HIVIAIDS. Later in the year, the authorities prepared a comprehensive National Strategy Framework (NSF) for HIVIAIDS, which consolidated all the related programs to address the epidemic and available donor support, and

\footnotetext{
${ }^{1}$ Under Article IV of the IMF's Articles of Agreement, the IMF holds bilateral discussions with members, usually every year. A staff team visits the country, collects economic and financial information, and discusses with officials the country's economic developments and policies. On return to headquarters, the staff prepares a report, which forms the basis for discussion by the Executive Board. At the conclusion of the discussion, the Managing Director, as Chairman of the Board, summarizes the views of Executive Directors, and this summary is transmitted to the country's authorities.
} 
is considered to be among the best in Africa. However, the NSF has not yet been issued as a Government policy paper, a prerequisite for its reconciliation with the NDP 9 and the annual budgets.

During 2003/04, productivity gains in the diamond-sorting process led to higher-than-expected real growth of 5.4 percent, as diamond production has surpassed the earlier expectation of 28 million carats to record 30 million carats, while nonmining output growth is projected to maintain 5 percent level for the second year in a row. Inflation declined during 2003, from over 12 percent in June to 6.4 percent in December 2003, reflecting mainly tight monetary policy and a moderation in the growth of government expenditure.

The overall fiscal outturn for $2003 / 04$ is likely to be nearly balanced against the announced intention to return to a long-standing tradition of surpluses. Some revenue items, notably the value-added tax (VAT), are expected to show a sizable shortfall compared with the budget, reflecting in part the weak tax administration, while expenditures on HIVIAIDS and drought relief will exceed the budget provisions.

The Bank of Botswana maintained a tight monetary policy stance throughout the second half of 2002 and in most of 2003 to stem inflationary pressures arising in part from high levels of government spending and the sharp increase in private sector credit. In addition, the total outstanding placement of the Bank of Botswana Certificates-the main instrument of liquidity control-increased to 10 billion pula (29 percent of GDP), as the authorities sought to drain the increase in banking system liquidity associated with the privatization of the public service pension system. The issue of government bonds (2.5 billion pula) in 2003 contributed to a further tightening of liquidity. As inflationary pressures abated, the Bank of Botswana cautiously eased policy by lowering the bank rate in steps from 15.25 percent to 14.25 percent by end 2003.

The pula is pegged to a currency basket comprising the rand and the SDR. It was devalued by 7.5 percent against the basket in February 2004 to partly reverse a steady real effective appreciation over the last two years. The external current account surplus is expected to have moderated to 11 percent of GDP in 2003, as the surge in diamond exports was offset by import growth (facilitated by a real appreciation of the pula), as well as a larger repatriation of profits and dividends. The authorities are implementing a number of structural reforms to improve access to export markets; these steps will help to maintain external competitiveness and promote diversification. End-year international reserves were US $\$ 5.3$ billion (23 months of imports).

\section{Executive Board Assessment}

Directors noted that Botswana's sound macroeconomic policies have contributed to sustained growth and single-digit inflation, which, together with strong institutions and prudent natural resource management, have helped place Botswana among the best-performing economies in Africa over the last three decades. At the same time, they observed that the leveling-off of diamond production is likely to slow the rate of growth in the period ahead, and very high 
HIVIAIDS infection rates threaten to undermine the remarkable progress that has been achieved in strengthening the economy and alleviating poverty. Against this background, Directors emphasized the need for policies aimed at diversifying the economy and sustaining growth, while providing for adequate resources to fight the HIVIAIDS pandemic. They welcomed the Ninth National Development Plan (NDP 9) as a timely and appropriate reflection of the authorities' medium-term economic strategy.

Directors commended the government on the launching of a comprehensive National Strategic Framework (NSF) for HIVIAIDS that consolidates all the programs related to the pandemic, as well as on the complementary National Strategy for Poverty Reduction (NSPR). They urged the authorities to integrate all these programs into the NDP 9 macroeconomic framework. This would facilitate the development of a common medium-term budgetary framework, and would assist the government in formulating an appropriate expenditure policy and mobilizing domestic resources to achieve the goal of a balanced budget. Directors supported the authorities' request for Fund technical assistance to strengthen the tracking of priority social expenditure.

Directors observed that the slowdown in economic growth, together with the HIVIAIDS pandemic, is expected to lead to a deterioration in Botswana's fiscal and external position even under optimistic assumptions. Against this background, Directors stressed the need to expedite reforms to strengthen tax administration by establishing an autonomous revenue authority with strong audit and enforcement functions, and a unit to monitor large taxpayers.

On the expenditure side, Directors encouraged the authorities to refine the fiscal rule, which earmarks diamond revenue to development expenditure by taking into account the changing composition of revenue and expenditure. Moreover, Directors underscored the need for a prompt reassessment of expenditure priorities to contain the rapid growth in government outlays. They urged the authorities to advance the expanded coverage of user fees on tertiary education and increases in fees for certain services of ministries and government departments, and to adjust utility charges as needed, while maintaining safety nets to protect access to public services by the poor and vulnerable groups.

Directors considered that the recent devaluation of the pula to partly reverse the real effective appreciation registered in recent years has resulted in a level of the exchange rate that is broadly appropriate but that needs to be supported by appropriately tight fiscal and monetary policies. In the medium term, Directors recommended considering more frequent reviews of the relative weights in the composition of the currency basket, to better reflect Botswana's trade pattern. Directors encouraged the authorities to continue implementing structural reforms to maintain external competitiveness and promote economic diversification. They supported the regional efforts to improve access to export markets; these efforts will need to be complemented with steps to privatize public enterprises, outsource certain government services, continue to remove impediments to private sector development, and promote reforms that could help Botswana benefit from business opportunities offered through regional cooperation initiatives. 
Directors welcomed the recent moderation in inflation, but felt that a more ambitious inflation target was needed to sustain the current exchange rate policy. They observed that the authorities' cautious interest rate policy is appropriate given the uncertain fiscal situation. Directors encouraged the authorities to improve the coordination of fiscal and monetary policies in order to reduce pressures on interest rates and foster private sector activities.

Directors concurred with the prominence given to financial sector reform in the NDP 9. The recent launching of an offshore center, the partial privatization of the civil servants' pension scheme, and the introduction of government bonds entail both opportunity for financial deepening as well as risks. Directors stressed that the increased risks associated with these reforms should be addressed through enhanced supervision, and they supported the authorities' request for Fund technical assistance in this area.

Directors welcomed the authorities' decision to review existing anti-money laundering legislation to determine if a free-standing anti-money laundering law is needed. They recommended that oversight of non-bank financial institutions be reinforced to reduce risks to stability and deter money-laundering.

Directors welcomed the progress made in improving statistical information, partly through Botswana's participation in the General Data Dissemination System (GDDS). However, further efforts are required to improve the timeliness and accuracy of macroeconomic data, better harmonize data, and broaden its coverage. Directors supported the provision of Fund technical assistance to strengthen the Central Statistics Office, which should be given adequate resources and a clear mandate to disseminate timely macroeconomic and social data.

It is expected that the next Article IV consultation with Botswana will be held on the standard 12-month cycle.

Public Information Notices (PINs) form part of the IMF's efforts to promote transparency of the IMF's views and analysis of economic developments and policies. With the consent of the country (or countries) concerned, PINs are issued after Executive Board discussions of Article IV consultations with member countries, of its surveillance of developments at the regional level, of post-program monitoring, and of ex post assessments of member countries with longer-term program engagements. PINs are also issued after Executive Board discussions of general policy matters, unless otherwise decided by the Executive Board in a particular case. The Staff Report for the 2003 Article IV Consultation with Botswana is also available. 
Selected Economic and Financial Indicators, 1999-2003

\begin{tabular}{|c|c|c|c|c|c|}
\hline & 1999 & 2000 & 2001 & 2002 & 2003 \\
\hline \multicolumn{6}{|l|}{ Output and Prices (change in percent) $1 /$} \\
\hline Real GDP 1/ & 6.6 & 8.4 & 2.3 & 5.5 & 5.4 \\
\hline of which: Private nonmining GDP & 3.4 & 3.1 & 4.5 & 5.6 & 5.2 \\
\hline Consumer prices (period average) & 7.8 & 8.5 & 6.6 & 8.0 & 9.3 \\
\hline \multicolumn{6}{|l|}{ Investment and savings (percent of GDP) $1 /$} \\
\hline Gross investment & 19.9 & 19.0 & 24.7 & 24.5 & 25.5 \\
\hline Public & 11.8 & 11.8 & 11.7 & 11.1 & 11.2 \\
\hline Private & 8.2 & 7.2 & 13.0 & 13.4 & 14.3 \\
\hline Gross domestic savings & 31.2 & 29.9 & 36.2 & 35.8 & 34.1 \\
\hline Public & 5.8 & 6.0 & 9.5 & 7.8 & 7.9 \\
\hline Private & 25.4 & 23.9 & 26.7 & 28.0 & 26.2 \\
\hline \multicolumn{6}{|l|}{ Central government finance $2 /$ (percent of GDP) } \\
\hline Total revenue and grants & 49.7 & 50.9 & 40.8 & 41.9 & 46.1 \\
\hline Total expenditure and net lending & 43.3 & 41.6 & 43.9 & 45.9 & 46.8 \\
\hline Overall balance (excluding grants) & 5.9 & 9.2 & -3.3 & -4.3 & -0.8 \\
\hline Overall balance (including grants) & 6.4 & 9.3 & -3.1 & -4.1 & -0.7 \\
\hline Primary balance & 6.8 & 9.6 & -2.8 & -3.8 & -0.5 \\
\hline Total public debt & 10.3 & 8.9 & 8.0 & 8.7 & 14.7 \\
\hline \multicolumn{6}{|l|}{ Money and credit $3 /$} \\
\hline Money and quasi money (end year; percentage change) & 26.3 & 1.4 & 31.2 & -1.1 & 12.6 \\
\hline Bank of Botswana lending rate (end year; in percent) & 13.3 & 14.3 & 14.3 & 15.3 & 14.3 \\
\hline \multicolumn{6}{|l|}{$\begin{array}{l}\text { External sector (millions of U.S. dollar) } 3 / \\
\text { External sector }\end{array}$} \\
\hline Trade balance & 785.6 & 904.5 & 713.8 & 763.3 & 997.7 \\
\hline Current account balance & 619.0 & 546.7 & 600.7 & 616.7 & 812.7 \\
\hline Gross official reserves & $6,229.2$ & $6,299.6$ & $5,926.7$ & $5,501.8$ & $5,281.7$ \\
\hline Botswana pula per U.S. dollar (period average) & 4.6 & 5.1 & 5.8 & 6.3 & 4.9 \\
\hline Real effective exchange rate (depreciation -) & 5.9 & 3.7 & 8.8 & 2.4 & 8.3 \\
\hline
\end{tabular}

Sources: Data provided by the Botswana authorities; and IMF Staff estimates.

1/ National accounts year beginning July 1; figures for 2002 and 2003 are estimates

2/ Fiscal year beginning April 1.

3/ Calendar year. 